\title{
Evolution of ore-forming fluids in the Bukovik-Kadiica porphyry Cu deposit, Republic of Macedonia
}

\author{
Goran Tasev ${ }^{1, *}$, Dalibor Serafimovski² and Todor Serafimovski ${ }^{1}$ \\ 1 University “Goce Delčev”, Faculty of Natural and Technical Sciences, Goce Delčev 89, 2000 Štip, Republic of Macedonia; \\ (corresponding author: goran.tasev@ugd.edu.mk) \\ 2 University “Goce Delčev”, Faculty of Electrical engineering, Goce Delčev 89, 2000 Štip, Republic of Macedonia
}

doi: $10.4154 / g c .2018 .01$

Article history:

Manuscript received June 12, 2017

Revised manuscript accepted September 21, 2017

Available online February 28, 2018

\begin{abstract}
The Bukovik-Kadiica mineralized system is hosted by Tertiary dacitic and andesitic volcanic rocks which have intruded the basement of Palaeozoic schists in the Serbo-Macedonian Massif of eastern Macedonia. The latest geological exploration has confirmed that this porphyry copper mineralization is characterized by a dominance of chalcocite and covellite with associated chalcopyrite, emplectite, and bornite, with the highest grades in a zone of supergene enrichment. Silicification is the dominant alteration within the mineralized system, whilst zones of potassic, phyllic, argillic, propylitic, and advanced argillic alteration are also present. Silicification and sulphide mineralization are located in stockworks in altered dacite and andesite breccia. Dissolution of primary sulphides and chemical leaching are evident in the zones of oxidation, dominated by limonite breccia. The main copper mineralization has a vertical extent between 90 and $220 \mathrm{~m}$. Fluid inclusion studies of mineralized quartz veins have identified three separate groups of fluids: saline inclusions which homogenize at $326-501{ }^{\circ} \mathrm{C}$ and have a salinity of $32-45 \mathrm{wt} \% \mathrm{NaCl}$ equiv., vapourdominated inclusions which homogenize at $438-497^{\circ} \mathrm{C}$ and have a salinity of $6-16 \mathrm{wt} \% \mathrm{NaCl}$ equiv., and more dilute, two-phase vapour-liquid inclusions that homogenize at $360-627^{\circ} \mathrm{C}$ and have a salinity of 3-24 wt\% $\mathrm{NaCl}$ equiv.
\end{abstract}

Keywords: Porphyry copper, fluid inclusions, hydrothermal alterations, Bukovik-Kadiica, Republic of Macedonia.

\section{REGIONAL GEOLOGICAL SETTING}

The Bukovik-Kadiica deposit is located in the Serbo-Macedonian Massif (SMM), which was described by DIMITRIJEVIC (1959) as a separate geotectonic and lithostratigraphic unit in the southern part of the Balkan Peninsula. The SMM is a crystalline basement complex boarded by the Vardar Zone to the west and by the Rhodope Massif to the east (Figs. 1 and 2). The SMM consists mainly of Palaeozoic gneisses and schists (KARAMATA, 1974a,b; KOCKEL et al., 1975, GRUBIĆ, 1980; DUMURDŽANOV et al., 2005), that have been intensely folded and faulted (BURCHFIEL et al., 2008a; ZAGORCHEV et al., 2008; ROBERTSON et al., 2009).

The SMM represents a wedge of continental crust developed as part of the Morava-Rhodope zone at the margin of the Tethys with Eurasia. It is thrust westwards over the Vardar zone and eastwards (Morava unit) over the Strouma unit. Precambrian (Upper Archaean to Proterozoic) and Vendian-Cambrian complexes (DIMITRIJEVIC, 1995; ZAGORCHEV \& MILOVANOVIC, 2006) are unconformably overlain by Lower Palaeozoic, Permian, Triassic, and Upper Cretaceous rocks. The Precambrian Ograzhdenian complex is composed of amphibolite-facies polymetamorphic and polydeformational rocks: gneisses, micaschists and amphibolites. It contains lenses of ultrabasic and basic rocks (serpentinites, harzburgites, lherzolites, norites), some of them transformed into eclogites. Migmatites and metagranites are present, as well. Recent data point toward tectonometamorphic amalgamation of very old (Late Archaean to Early Proterozoic) oceanic crust with Precambrian continental crust, a major Cadoinclusion analysis. 
mian tectonometamorphic event, Ordovician metagranites, and Late Hercynian post-metamorphic granites (ZAGORCHEV et al., 2008; ZAGORCHEV et al., 2015). A Vendian-Cambrian greenschist-facies complex (Vlasina Group, Frolosh Formation) has a thickness estimated between 1 and $4-5 \mathrm{~km}$, and composition made of chlorite and actinolite schists, metasandstones, metaconglomerates, and metadiabases. Metabasic rocks (gabbros) are also present. Zircon data indicate an age of c. 560-570 Ma (GRAF, 2001).

BOYANOV et al. (1989) and DABOVSKI et al. (2002) considered the Alpine evolution of the region as a sequence of opening and closing of epicontinental basins with the formation of separate collisional orogens at the north-eastern side of the active plate (Tethys) margin, whereas the Tethys ocean itself evolved by the opening of several seaways between comparatively stable zones of similar lithologies. Although the closure of the Vardar ocean occurred in the late Mid Jurassic to Late Jurassic times, these isopic zones continued their evolution throughout the whole remaining part of the Mesozoic and most of the Cenozoic, with the youngest marine sediments of Pliocene age (ZAGORCHEV et al., 2008; DUMURDŽANOV et al., 2004) (Fig. 1).

Numerous geological structures controlled emplacement of magmatic rocks and associated mineralization (JANKOVIĆ \& PETKOVIĆ, 1974; JANKOVIĆ et al., 1980; SERAFIMOVSKI, 1990). The Tertiary volcanic activity along reactivated Cenozoic structures (ARSOVSKI \& IVANOV, 1977; SERAFIMOVSKI, 1990, 1993), is usually accompanied by polymetallic mineraliza- tion of $\mathrm{Pb}, \mathrm{Zn}, \mathrm{Cu}, \mathrm{Au}, \mathrm{Ag}, \mathrm{As}$, and Sb type (JANKOVIĆ et al., 1980; SERAFIMOVSKI et al., 1995; JANKOVIC \& SERAFIMOVSKI, 1997). Major structures in the central parts of the SMM have also been related to distinct and productive $\mathrm{Cu} \pm \mathrm{Au} \pm \mathrm{Ag} \pm \mathrm{Mo}$ mineralizations (SERAFIMOVSKI et al., 2010). Neotectonic SW-NE to E-W directed structures are not related to the mineralizations but are still seismically active (BURCHFIEL et al., 2008b).

\section{GEOLOGICAL FEATURES}

The Bukovik-Kadiica mineralized system spatially belongs to the Besna Kobila-Osogovo-Thasos structural-metallogenetic zone (e.g., JANKOVIĆ \& PETKOVIĆ, 1974; JANKOVIĆ et al., 1980; SERAFIMOVSKI, 1990; SERAFIMOVSKI et al., 1995; JANKOVIC \& SERAFIMOVSKI, 1997). This metallogenetic zone has been formed along the eastern Serbo-Macedonian block, stretching parallel to the Carpathian-Balkan tectonic unit and western parts of the Rhodope block (ZAGORCHEV, 1995; ZAGORCHEV et al., 1987). This regional metallogenetic unit is $250 \mathrm{~km}$ long (JANKOVIC, 1997; JANKOVIC et al., 1997) and is controlled by major fracture zones and spatial distribution of Tertiary magmatism (Fig. 2).

The mineralization is related (HARKOVSKA et al., 1989; STOJANOV et al., 1995; BOEV et al., 1997; BOEV \& YANEV, 2001) to calc-alkaline complexes (rhyolite-quartz-latite-dacite/ andesite), which occur intermittently along the fracture zones from the Oligo-Miocene to Lower Early Pliocene time, between

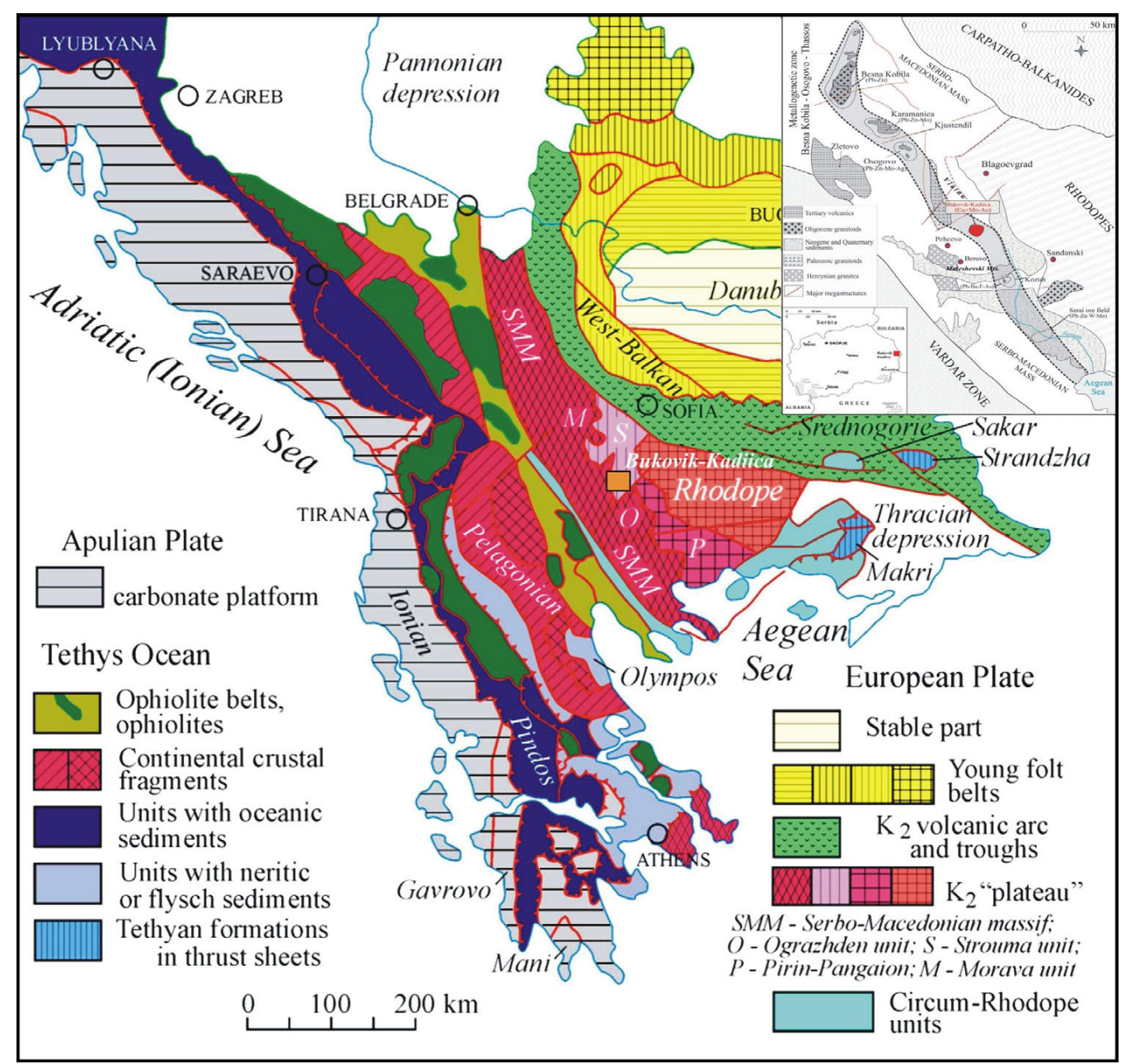

Figure 1. The geotectonic position of the Jurassic ophiolites and ophiolitic belts in the central parts of the Balkan Peninsula (ZAGORCHEV et al., 2012). 


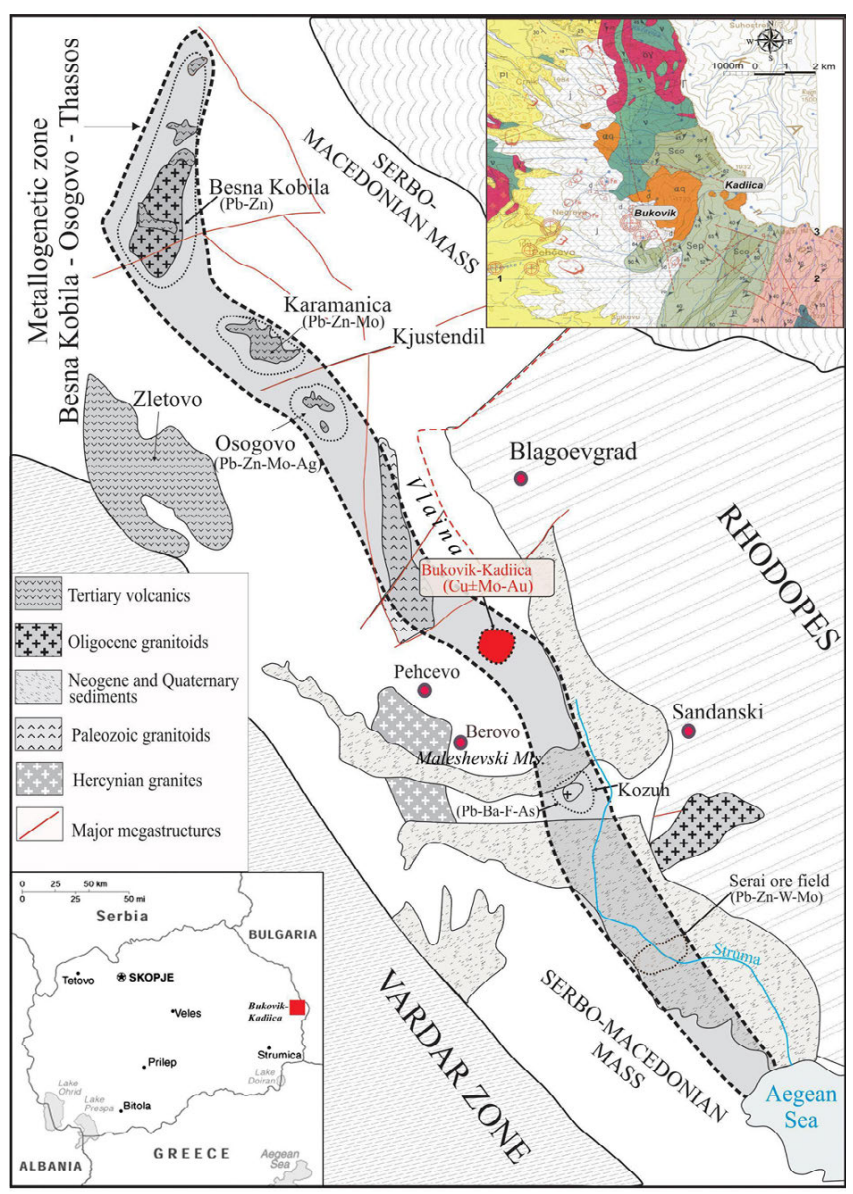

Figure 2. A structural-metallogenetic scheme for the Besna Kobila-OsogovoThasos zone (modified after JANKOVIĆ et., 1997).
25 to and 14 Ma. Base metal mineralization (lead and zinc sulphides) dominate within this metallogenetic zone, with local occurrences of molybdenite and scheelite (stockwork-disseminated type mineralization and hydrothermal quartz veins), low-temperature stibnite, fluorite deposits and occasional cinnabar and barite occurrences.

Longitudinal zoning of mineral associations is well developed in the NW-SE direction (SERAFIMOVSKI et al., 1997). The most important types of mineralization are:

- Skarn mineralization related to intercalations of marble in Precambrian crystalline schist within the the Serbo-Macedonian massif. Mineralization occurs in lenticular and stratabound ore bodies (e.g. the Sasa $\mathrm{Pb}-\mathrm{Zn}$ deposit).

- Hydrothermal stockwork mineralization developed along fault structures (e.g. Baltašnica $\mathrm{Pb}-\mathrm{Zn}-\mathrm{Cu}$ deposit).

- Hydrothermal veins emplaced in different lithological settings (common but mostly small and non-economic).

The Bukovik-Kadiica area is composed mainly of RipheanCambrian and Palaeozoic metadiabases and schists (a diabasephyllite complex, Vlasina complex) that have experienced greenschist facies metamorphism and display a well-developed schistosity. Near Berovo they directly overlie amphibolite-facies gneisses (KARAMATA, 1974A; KOCKEL et al., 1975, GRUBIĆ, 1980; DUMURDŽANOV et al., 2005).

Metadiabase and schist are cross-cut by dykes of younger gabbro and diabase. The age of the Kadiica Formation is postVendian and pre-Permian (ZAGORCHEV, 1987), with metadiabases and schists discordantly covering the older Frolosh Formation (Vlasina complex) at 530-550 Ma (the U-Pb zircon dating by GRAF, 2001; KOUNOV, 2002; ZAGORCHEV et al., 2011A,B, 2012; KOUNOV et al., 2012; KISELINOV et al., 2014;
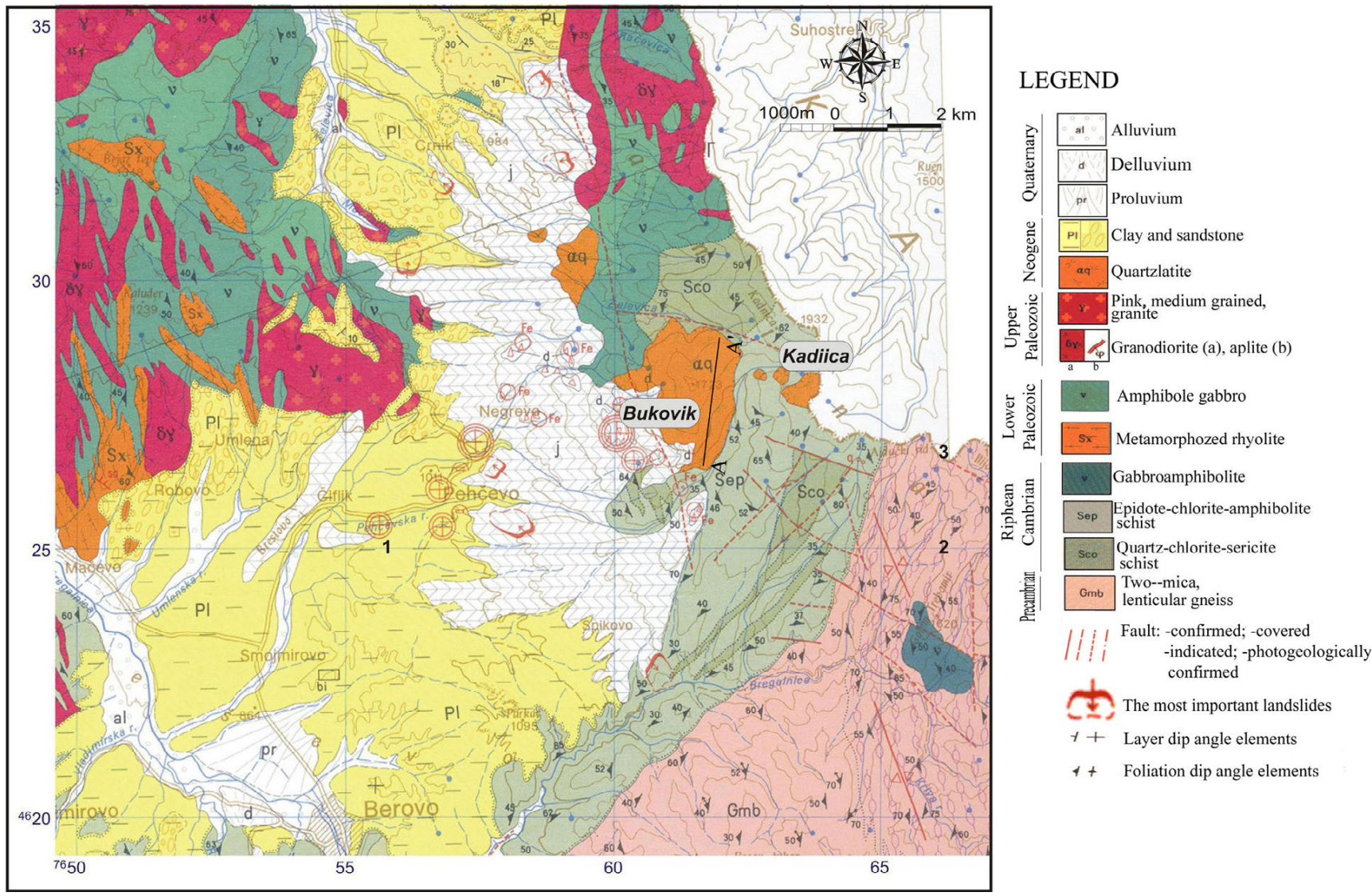

Figure 3. Geological map of the Bukovik-Kadiica locality (modified after DUZELKOVSKI, 1960). 


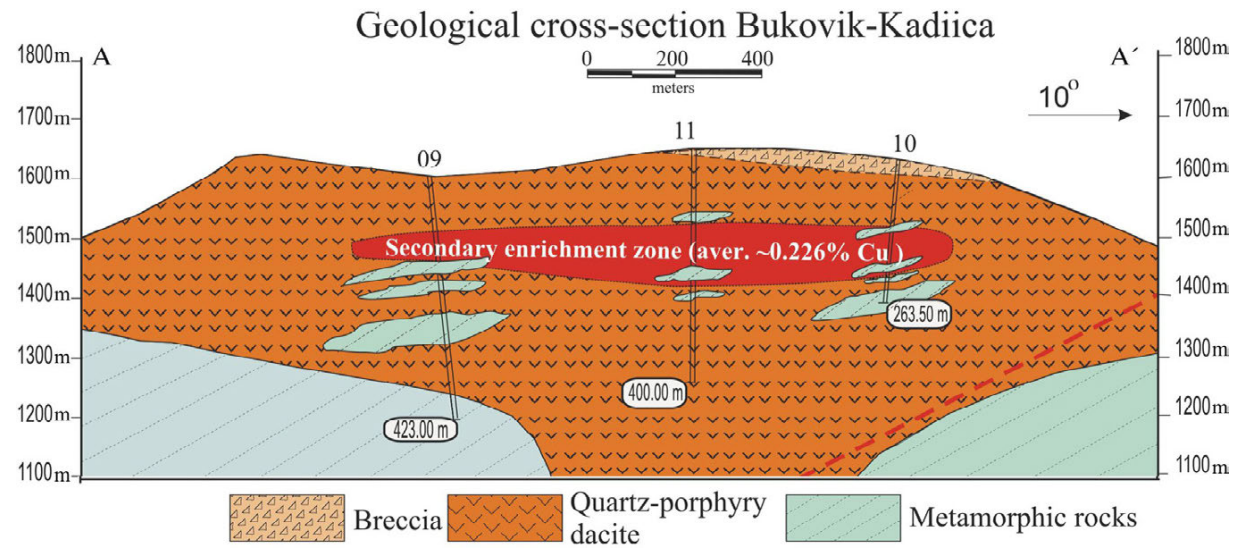

Figure 4. Geological cross section of the Bukovik-Kadiica locality (TASEV, 2010) (the presence of metamorphic enclaves is idealized and these are probably more extensive than shown).

ANTIĆ et al., 2015). To the west the zone is bounded by a Tertiary graben filled with Eocene and Pliocene sediments.

North of Belo Brdo towards Kriva Buka and Pančarevo, granitoids dominate. They are represented by granites, granite porphyries, and granodiorites. These igneous rocks build up a belt along the Macedonian-Bulgarian border. To the west, they subsided into the Pehčevo-Delčevo graben, and are covered with Tertiary (Palaeogene and Neogene) sediments. The oldest rocks present are diorites, and they are cross-cut by granite-porphyries and granodiorites. They are all thought to be of Palaeozoic age (STOJANOV et al., 1995). The granite-porphyries are a marginal facies of the Hercynian Delčevo granites. Their age is proven by the presence of granite fragments within the younger Permian and Triassic conglomerates. The granitoids are cross-cut by diabase dykes near Pančarevo. The granitoids are hydrothermally altered, most probably due to post-magmatic hydrothermal processes associated with the Tertiary volcanic rocks.

Permian sediments (sands and claystone) lie transgressively over metagabbro-diabases and granodiorites. Palaeogene products are represented by Eocene sediments that, in accordance with their lithological features and superposition of layers, can be distinguished into grey conglomerate facies (conglomerate, breccia, sand, clay, and marl) and flysch facies (yellow sand with occasional intercalations of silty clays and microconglomerates with rhythmic alternation).

\section{MAIN GEOLOGICAL FEATURES OF THE DEPOSIT}

Tertiary volcanism in the Bukovik-Kadiica area is represented by the Bukovik volcanic dome (1722 m) and small subvolcanic bodies of dacite and rhyodacite at Belo Brdo and Kadiica (1932 m) covering an area of about $4 \mathrm{~km}^{2}$. Small dacite bodies and dykes were discovered in Bulgarian territory within a NW-SE oriented zone, as well as a cryptodome with subvolcanic breccias at the intersection of faults of N-S and NE-SW strikes (HARKOVSKA, 1984). The Kadiica subvolcanic intrusive centre is one of several Neogene dacitic plugs that have intruded a variety of metamorphic rocks of the SMM. Several of these intrusives are associated with quartz vein stockwork development and widespread hydrothermal alteration. The subvolcanic intrusive complex is poorly exposed on Bukovic Hill (1722 m asl) and consists of flow-banded dacite and massive fine crystalline dacite that have been intruded by a coarser dacite phase, a quartz-, biotite-, and plagioclasephyric dacite porphyry, and a postulated second dacite porphyry at depth. Near-surface pyroclastics and dacitic autobreccias are exposed along the southwest side of Bukovic Hill. According to HARKOVSKA (1984), HARKOVSKA et al. (1989), and STOJANOV et al. (1995), the Kadiica intrusive complex has been dated as between 35 and $27 \mathrm{Ma}$ (Oligocene; whole rock, K/Ar method). An extensive area of brecciation consists predominantly of tectonic breccias associated with a northwest-southeast-striking major fault zone. Late stage phreatic or phreato-magmatic breccias are intercepted at shallow levels in exploration drill holes (Fig. 1).

The subvolcanic intrusive complex has been intensely altered and is cut by numerous quartz, quartz-sulphide, and sulphide veins and veinlets. Surface alteration is dominated by silicification with abundant limonite as disseminations and in veins with lesser amounts of kaolinite, sericite, and local alunite. The petrography of selected samples shows the presence of a near-surface advanced argillic overprint characterized by alunite with local diaspore and andalusite. Alteration and metal zoning suggest the presence of a deeper dacite porphyry phase that was responsible for the formation of the large stockwork exposed at Bukovic Hill. Alteration and weak copper mineralization are hosted by an Oligocene dacitic volcanic complex (TASEV, 2010), which has intruded into Palaeozoic sediments, andesites, and gabbros (Fig. 4).

In particular, because the life span and thermal evolution of the hydrothermal system plays a major role in the understanding of the genesis of a particular hydrothermal ore deposit, this study has attempted to establish some constraints on the thermal evolution of the magmatic-hydrothermal system at the Kadiica porphyry copper deposit using fluid inclusion analysis.

\section{HYDROTHERMAL ALTERATION}

Hydrothermal alterations of the host rocks (dacite, trachydacite, and granodiorite) within the Bukovik-Kadiica deposit are widespread and distinctive and they reflect the spatial and temporal evolution of hydrothermal fluids. The overall form of the alteration system has a pin-like shape and distinctive alteration types overlap each other like layers of an onion (Fig. 4). The alterations and the porphyry $\mathrm{Cu}$ mineralization show an intimate genetic relationship. The overprint of older alteration zones by younger alterations reveals a sequential evolution of hydrothermal fluids and indicates that the alteration processes had a dynamic and complex character. The study and description of deep hypogene hydrothermal features have been complicated by a relatively deeply 

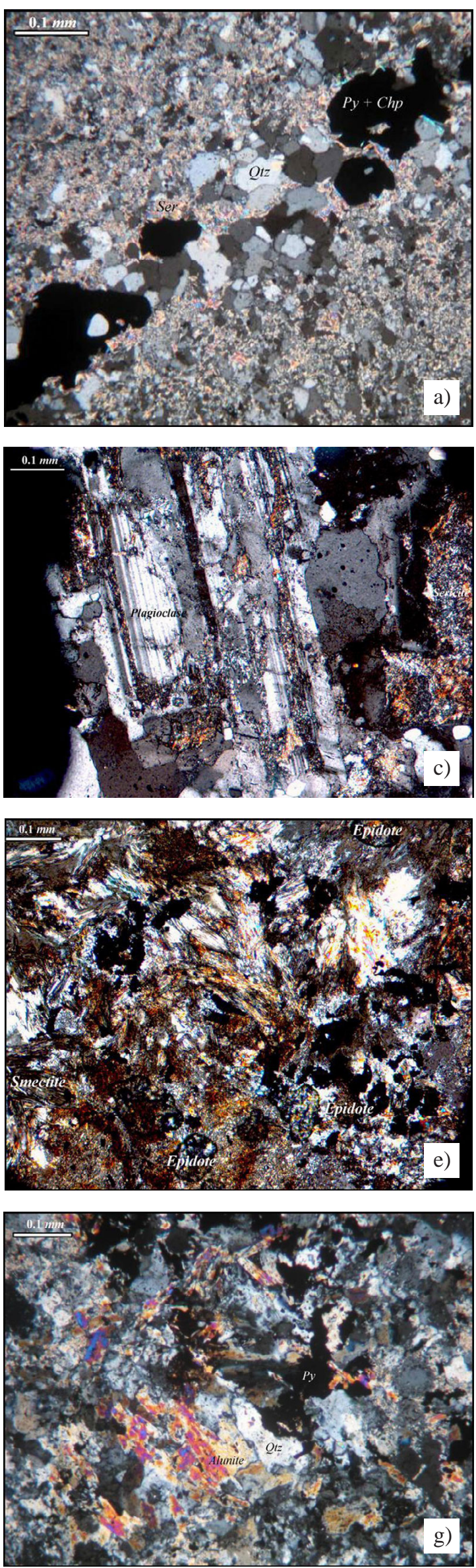
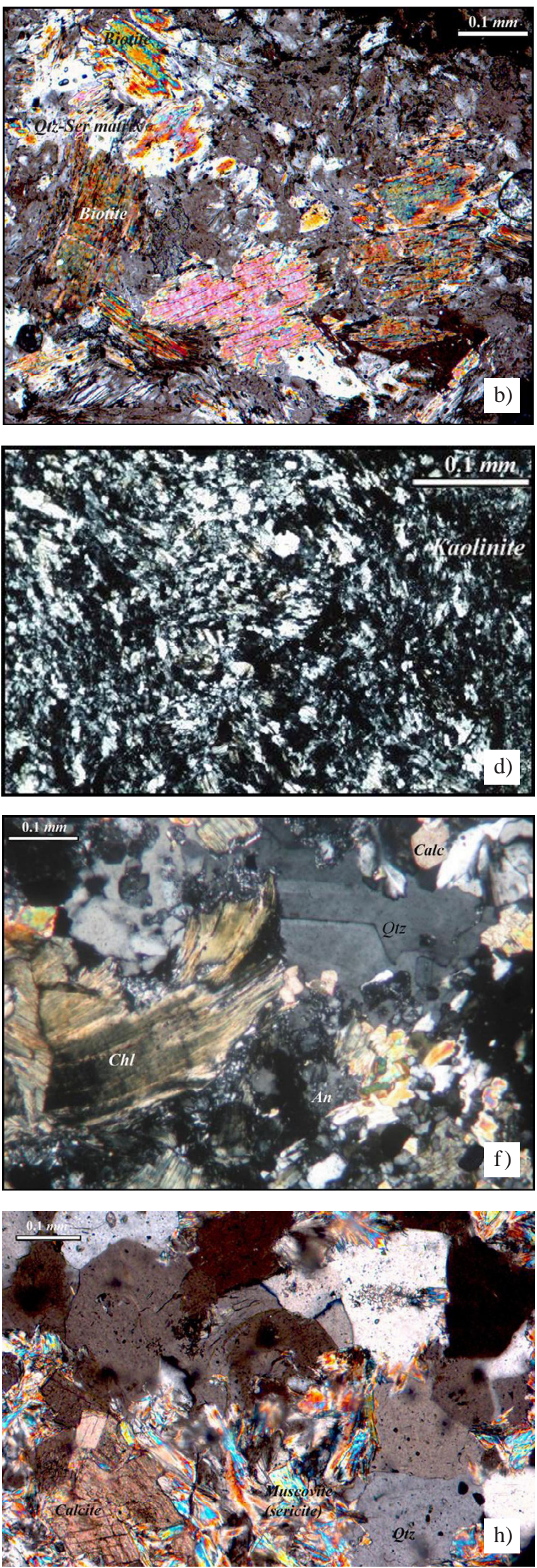

Figure 5. a) Quartz-sericite assemblage alteration; b) Quartz-sericite-biotite assemblage alteration; c) Plagioclase relics in quartz-sericite assemblage alteration; d) Coarse grained kaolinite alteration; e) Epidote-smectite assemblage alteration; f) Quartz-chlorite-calcite assemblage alteration; g) Quartz-alunite assemblage alteration; h) Quartz-muscovite (sericite)-calcite assemblage alteration. 


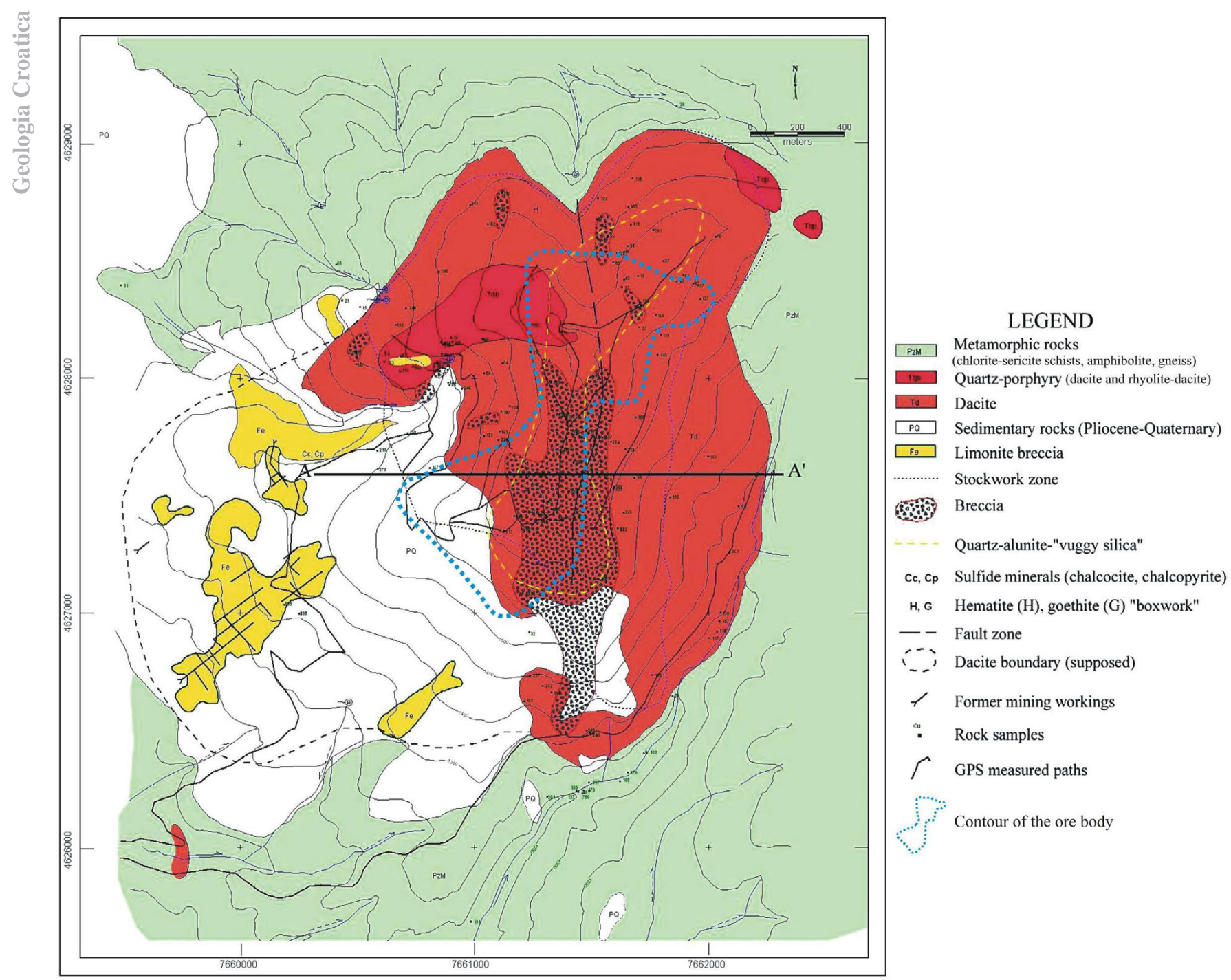

Figure 6. Geological map of the Bukovik-Kadiica deposit (ALEXANDROV \& BOMBOL, 2007).

penetrating advanced argillic overprint and by subsequent supergene alteration that modified both the deep and shallow hydrothermal features.

The distribution of hydrothermal alterations at the BukovikKadiica porphyry $\mathrm{Cu}$ deposit differs from the common alteration zonation, with a potassic core, a phyllic alteration halo and a wider peripheral propylitic zone (e.g., LOWELL \& GUILBERT, 1970; RUSK et al., 2008). In contrast, this deposit is characterized by distant zones of potassic, phyllic, argillic, propylitic, and an advanced argillic character as well as by the presence of limonitization.

Potassic alteration is represented by the mineral assemblage composed of K-feldspar, quartz, biotite and/or magnetite, amphibole, and anhydrite. Magmatic biotite has been partly replaced by a Mg-rich variety associated with rutile. This is the most widespread alteration type in the Bukovik-Kadiica ore district, located just above the granodiorite intrusion, but the biotite halo occupies a much wider area. Usually potassic alteration is overprinted by lower temperature hydrothermal alteration assemblages. In the mineralized porphyry rocks and surrounding dacite-trachydacite, K-feldspar occurs as irregular replacements of the igneous matrix while in more pervasively altered samples it replaced the phenocrysts and destroyed the original igneous texture. Similar fea- tures have been recognized in porphyry $\mathrm{Cu}$ deposits elsewhere (e.g. LI et al., 2013).

Phyllic alteration overprints the potassic alteration and at places is very intensive. It may form a wide halo around the mineralization, although it is also closely associated with the Cu mineralization itself. Its vertical extensions significantly exceed the horizontal dimensions. This type of alteration is characterized by the presence of quartz, sericite, and disseminated pyrite (Fig. 5a). Sericite is present as aggregates, while orthoclase and biotite are extensively altered to muscovite and partly to secondary biotite; primary biotite is altered to sericite (Fig. $5 \mathrm{~b}$ ), and sericite has replaced plagioclase phenocrysts (Fig. 5c). This type of alteration contains a significant amount of pyrite that is directly associated with the alteration process. Phyllic alteration overlaps with the central parts of the mineralized zone (red zone shown in Fig. 4), while the argillic alteration zone characterized by kaolinite replacement progresses outwards. Similar features have been recognized in other porphyry $\mathrm{Cu}$ deposits such as Buchim (ČIFLIGANEC, 1993), Borov Dol (GJORGJEVIC et al., 1975), Morenci, Ajo and Bisbee (NASH, 1976; MISRA, 2000).

Argillic alteration is intensive, but distal from the granodiorite intrusion, and is characterized by newly formed kaolinite at the expense of plagioclase. The primary textures are partly or 
completely obscured, although quartz phenocrysts can still be recognized. Primary plagioclase was replaced by kaolinite (usually closer to the intrusion area, Fig. 5d), while montmorillonite occurs at higher levels (where hypogene mineralization is almost insignificant).

The propylitic alteration zone is the dominating feature of the great majority of porphyry $\mathrm{Cu}$ deposits, for example at Plavica in the Republic of Macedonia (IVANOV \& DENKOVSKI, 1980; STOJANOV, 1980) as well as in deposits in the Collahausi district-Rosario, Ujina, and Quebrada Blanca, then the Los Loros, Los Pelambres, Bajo de la Alumbrera, Chuiquicamata deposits (all in Chile), (TAYLOR, 1935; SILLITOE, 1973; URQUETA et al., 2009). At the Bukovik-Kadiica deposit this alteration type is represented by a mixture of epidote, smectite chlorite, calcite, talc, and kaolinite (Figures 5e, 5f). Spatially, propylitic alteration characterizes the marginal parts of the hydrothermal system where fluid/rock ratios were the lowest. Epidotization and chloritization were mainly associated with weak porphyry mineralization.

The uppermost part of the Bukovik-Kadiica deposit is characterized by an advanced argillic alteration zone predominantly composed of quartz-, kaolinite, pyrite ( \pm limonite), rutile and alunite (Fig. $5 \mathrm{~g}$ ). The mineral assemblage suggests extremely low $\mathrm{pH}$ conditions and it is a common assemblage for shallow parts of porphyry Cu deposits worldwide (e.g., SILLITOE, 1973; GUSTAFSON \& HUNT, 1975; BRIMHALL, 1979; THOMPSON et al., 1986; LINDHORST \& COOK, 1990; WORMALD \& PRICE, 1990). In some places, the surface of the advanced argillic alteration zone is covered by a very thin iron cap.

Carbonatization, although minor, occurs within the Bukovik-Kadiica deposit. However, precipitation of calcite succeeds - sulphide mineralization (Figure 5h).

\section{MINERALIZATION}

The mineralized area $\left(4 \mathrm{~km}^{2}\right)$ consists of numerous dacite and rhyolite-dacite bodies and dykes that extruded through the SMM basement of metamorphic rocks, represented mainly by chlorite-sericite schists, amphibolite and gneiss in the lowest parts (Figure 6).

Emplacement and subsequent cooling of the complex resulted in intensive fracturing and brecciation. Mineralized bodies have different lens-like morphologies, with a NE-SW orientation, mostly due to differences in permeability of the host structures.
The Bukovik-Kadiica deposit consists of of three distinctive mineralized zones:

- a primary sulphide zone or hypogene mineralization

- a secondary Cu sulphide enrichment zone or cementation zone

- an oxidation zone

Data collected from the drill cores revealed that a hypogene zone occurs at depths between 64 to $420 \mathrm{~m}$, and has a variable thickness of 10 to $183 \mathrm{~m}$. The $\mathrm{Cu}$ content ranges from $0.007 \mathrm{up}$ to $0.13 \%$. In the deeper parts, the mineralization occurs in veins which mutually intersect. The most enriched stockworks were found at greater depths (>200 m) in dacites. So far, significant hypogene mineralization has not been confirmed.

The secondary $\mathrm{Cu}$ sulphide enrichment (cementation) zone (Figure 7) occurs at depths from 60 to $260 \mathrm{~m}$ below the surface, with an average thickness of $70 \mathrm{~m}$, and reflects the level of ground water during deposition of the secondary mineralization. The horizontal dimensions of this zone are $1200 \mathrm{~m} \mathrm{x} 700 \mathrm{~m}$. It contains $70 \mathrm{Mt}$ of ore with an average grade of $0.22 \% \mathrm{Cu}(\mathrm{B}+\mathrm{Cl}$ category by the Macedonian Law of Mineral Resources and appropriate rulebook). Gold and silver contents appear to be low (Au $<0.6 \mathrm{~g} / \mathrm{t}$; $\mathrm{Ag}$ up to $250 \mathrm{~g} / \mathrm{t}$, but usually $<50 \mathrm{~g} / \mathrm{t}$ ). These ore reserves are economically exploitable and their calculation was based on $0.15 \% \mathrm{Cu}$ cut-off grade (SERAFIMOVSKI, 2012). The secondary $\mathrm{Cu}$ sulphide enrichment zone consists predominantly of chalcocite, pyrite, molybdenite, chalcocite, bornite, covellite, digenite, tetrahedrite-tennantite series minerals, as well as arsenosulvanite, colusite, and mawsonite (TASEV, 2010). The $\mathrm{Cu}$ distribution clearly defines the leached zone and an enriched copper zone with chalcocite precipitated far below the base of the oxidation zone. The chalcocite/covellite ratio changes vertically from the chalcocite predominant shallow parts to the covellite predominant deeper parts of the zone. However, the $\mathrm{Cu}$ distribution in the deeper part within the majority of drilled holes does not show a clear enrichment trend. Figure 8 illustrates the complete paragenetic sequence at the Bukovik-Kadiica deposit (Fig. 8).

The paragenetic sequence distinguishes an early magmatic mineral assemblage composed of rutile, magnetite, haematite and pyrite. However, the majority of the pyrite was deposited simultaneously with the propylitic alteration.

The vast majority of ore minerals, including pyrrhotite, molybdenite, pyrite, chalcopyrite, sphalerite, enargite, galena, tetra-

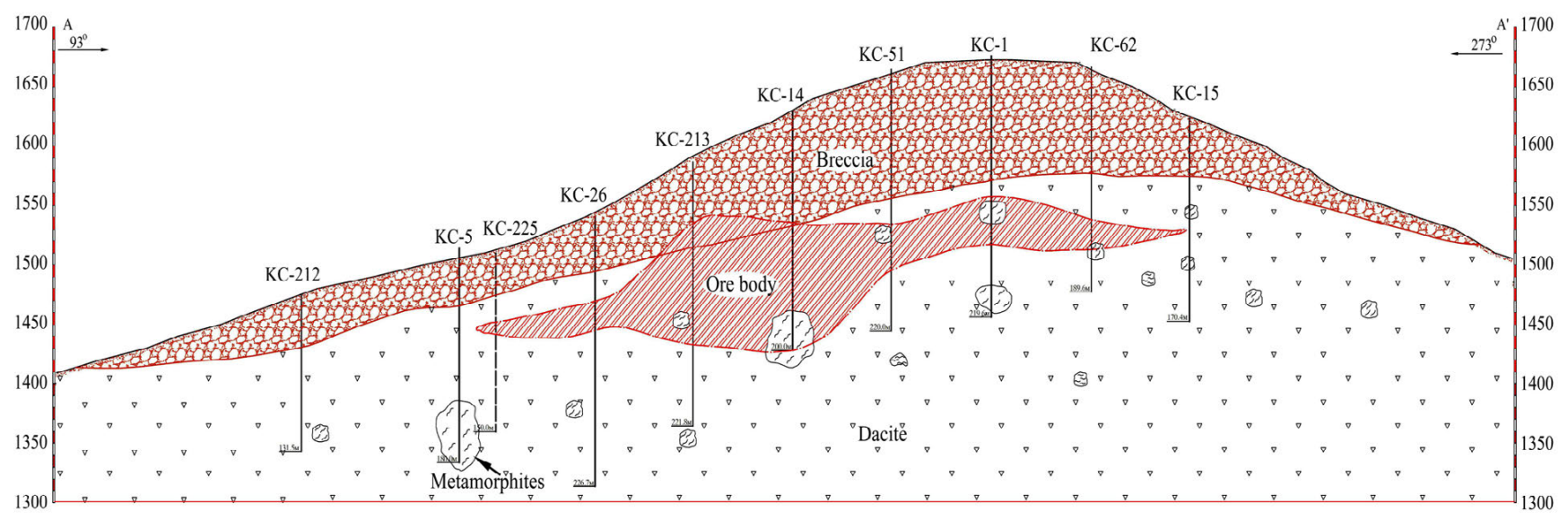

Figure 7. Cross section through the Bukovik-Kadiica deposit. 


\begin{tabular}{|c|c|c|c|c|c|c|c|c|c|c|}
\hline \multirow[t]{2}{*}{ No. } & \multirow{2}{*}{$\begin{array}{l}\text { Stage } \\
\text { Minerals }\end{array}$} & \multirow{2}{*}{$\begin{array}{c}\text { Magmatic } \\
\text { stage }\end{array}$} & \multirow{2}{*}{$\begin{array}{c}\text { Stage of } \\
\text { hydrothermal } \\
\text { alterations }\end{array}$} & \multicolumn{6}{|c|}{ Ore-bearing stage } & \multirow{2}{*}{$\begin{array}{c}\begin{array}{c}\text { Supergene } \\
\text { stage }\end{array} \\
\end{array}$} \\
\hline & & & & $\begin{array}{l}\text { I } \\
\text { sub- } \\
\text { stage }\end{array}$ & \begin{tabular}{|l|} 
II \\
sub- \\
stage
\end{tabular} & \begin{tabular}{|l|} 
III \\
sub- \\
stage \\
\end{tabular} & $\begin{array}{l}\text { IV } \\
\text { sub- } \\
\text { stage }\end{array}$ & $\begin{array}{l}\mathrm{V} \\
\text { sub- } \\
\text { stage }\end{array}$ & $\begin{array}{l}\mathrm{VI} \\
\text { sub- } \\
\text { stage }\end{array}$ & \\
\hline 1 & Magnetite & & & & & & & & & \\
\hline 2 & Pyrite & & & & & & & & & \\
\hline 3 & Martite & & & & & & & & & \\
\hline 4 & Hematite & & & & & & & & & \\
\hline 5 & Chlorite & & & & & & & & & \\
\hline 6 & Calcite & & & & & & & & & \\
\hline 7 & Sericite & & & & & & & & & \\
\hline 8 & Quartz & & & & & & & & & \\
\hline 9 & Kaolinite & & & & & & & & & \\
\hline 10 & Smectite & & & & & & & & & \\
\hline 11 & Rutile & & & & & & & & & \\
\hline 12 & Pyrrhotite & & & & & & & & & \\
\hline 13 & Chalcopyrite & & & & & & 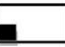 & & & \\
\hline 14 & Sphalerite & & & & & & & & & \\
\hline 15 & Bornite & & & & & & & & - & \\
\hline 16 & Galena & & & & & & & & & \\
\hline 17 & Molybdenite & & & 르 & & & & & & \\
\hline 18 & Tennantite & & & & & & & & & \\
\hline 19 & Tetrahedrite & & & & & & & & & \\
\hline 20 & Enargite & & & & & & & & & \\
\hline 21 & \begin{tabular}{|l} 
Luzonite \\
\end{tabular} & & & & & & & & & \\
\hline 22 & Famatinite & & & & & & & & & \\
\hline 23 & Covellite & & & & & & & & & \\
\hline 24 & Chalcocite & & & & & & & & & \\
\hline 25 & \begin{tabular}{|l} 
Digenite \\
\end{tabular} & & & & & & 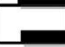 & & & \\
\hline 26 & Colusite & & & & & & & & & \\
\hline 27 & Arsenosulvanite & & & & & & & & & \\
\hline 28 & Mawsonite & & & & & & & & & \\
\hline 29 & \begin{tabular}{|l} 
Proustite \\
\end{tabular} & & & & & & ב & & & \\
\hline 30 & Pyrargyrite & & & & & & & & & \\
\hline 31 & Goethite & & & & & & & & & \\
\hline 32 & Alunite & & & & & & & & & \\
\hline 33 & Diaspore & & & & & & & & & \\
\hline 34 & Epidote & & & & & & & & & \\
\hline 35 & Malachite & & & & & & & & & 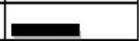 \\
\hline 36 & Azurite & & & & & & & & & \\
\hline 37 & \begin{tabular}{|l} 
Wittichenite \\
\end{tabular} & & & & & & & & & \\
\hline 38 & Emplectite & & & & & & & & & \\
\hline 39 & Biotite & & & & & & & & & \\
\hline 40 & Andalusite & & & & & & & & & \\
\hline 41 & \begin{tabular}{|l} 
Limonite \\
\end{tabular} & & & & & & & & & \\
\hline 42 & IImenite & & & & & & & & & \\
\hline 43 & Deposition of Fe & & & & & & & & & \\
\hline 44 & Deposition of $\mathrm{Cu}$ & & & & & & & & & \\
\hline 45 & Deposition of As & & & & & & & & & \\
\hline 46 & Deposition of $\mathrm{Pb}$ & & & & & & & & & \\
\hline 47 & Deposition of S & & & & & & & & & \\
\hline 48 & Deposition of Sb & & & & & & & & & \\
\hline
\end{tabular}

Figure 8. The paragenetic sequence of the Bukovik-Kadiica deposit.

hedrite, tennantite, famatinite, luzonite, proustite, and pyrargirite, was deposited during Substage III (Fig. 8).

The oxidation zone is fully developed and represented by limonite-silica masses. Magnetite, chalcopyrite, rutile, haematite, and calcite have also been registered. Copper concentrations in this zone ranges from $0.003-0.12 \% \mathrm{Cu}$ while the thickness (from the surface) varies from $20-130 \mathrm{~m}$. Copper was intensively mobilized and carried out of this zone, which is a common feature of pyrite-bearing mineralizations. Oxidation of pyrite signifi- cantly decreases $\mathrm{pH}$ values and promotes mobilization of all metals, including $\mathrm{Cu}$. A carbonate rich lithology buffers the $\mathrm{pH}$ value of descending ground waters and allows deposition of malachite and azurite.

\section{FLUID INCLUSION METHODOLOGY}

The mineralization in the Bukovik-Kadiica area has been studied using a variety of chemical and mineralogical techniques. Intensive exploration activity was carried out during 2011 and 2012 

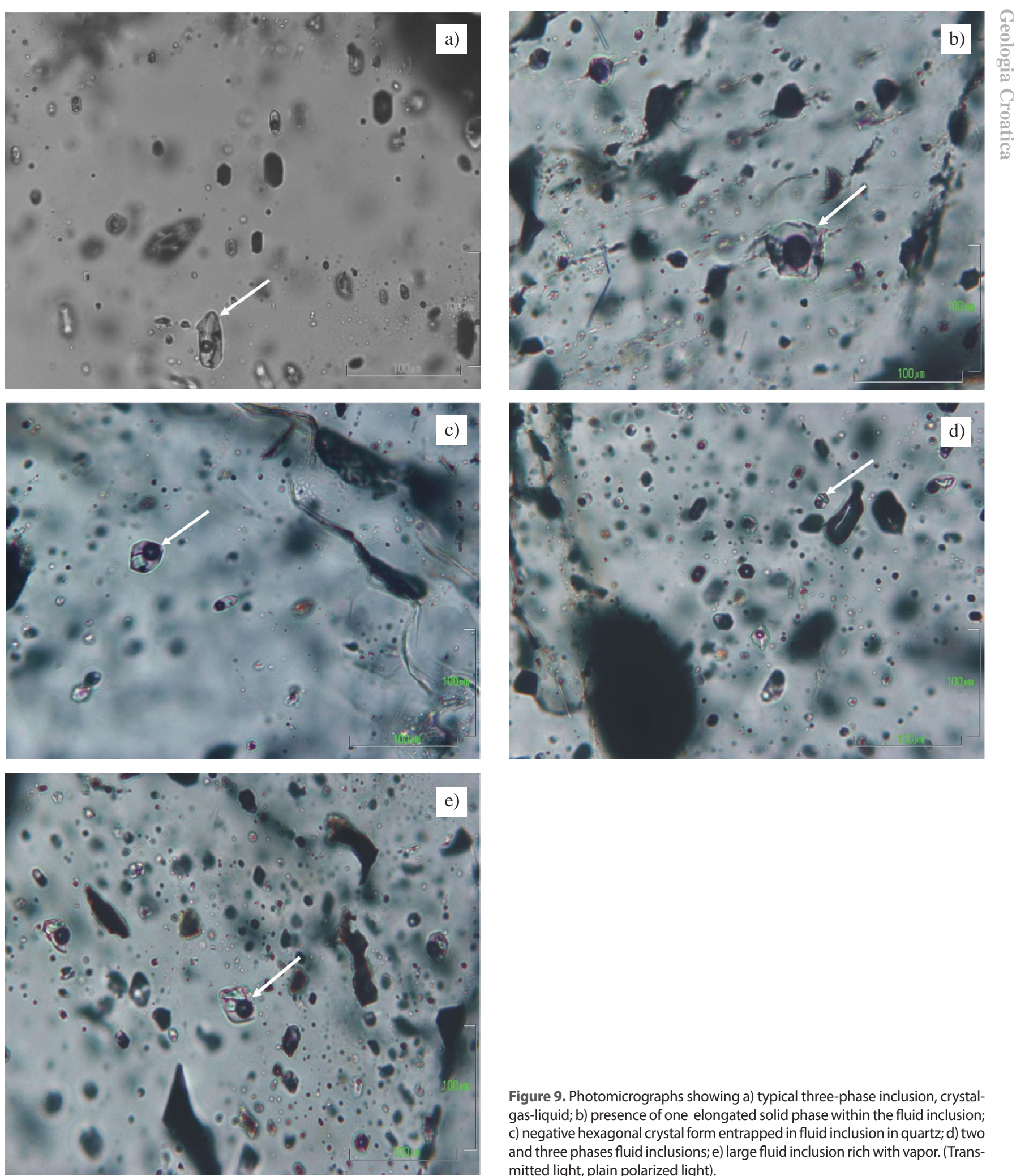

Figure 9. Photomicrographs showing a) typical three-phase inclusion, crystalgas-liquid; b) presence of one elongated solid phase within the fluid inclusion; c) negative hexagonal crystal form entrapped in fluid inclusion in quartz; d) two and three phases fluid inclusions; e) large fluid inclusion rich with vapor. (Transmitted light, plain polarized light).

(including 16,500 $\mathrm{m}$ of drill core); and based on these findings reserves of $70 \mathrm{Mt}$ at a grade of $0.216 \% \mathrm{Cu}$ were estimated. At the same time as the exploration proceeded, detailed mineralogical and geochemical studies were performed (TASEV, 2010). More detailed descriptions of the mineralization, focusing on the fluid inclusions in mineralized quartz samples are the target of the research (drill holes 09, 10, 11 complemented with those from 01 and 08). A fluid inclusion study was conducted on 23 samples of doubly polished, transparent plates of quartz, $150 \mu \mathrm{m}$ thick, with numerous separate fluid inclusions $(5-40 \mu \mathrm{m}$ in size). Quartz was selected from veinlets in dacites and fluid inclusions in calcites were also occasionally analysed (TASEV, 2010). Quartz samples were taken from stockworks which were exposed along a surface section over more than $100 \mathrm{~m}$ and from drill cores. Fluid inclusions were evenly distributed in the studied quartz grains and only those with strong indications of primary origin (GOLDSTEIN \& REYNOLDS, 1994), were taken into account during the microthermometric studies (ROEDDER, 1984). 
The study was performed using Nikon and Olympus BX51 optical microscopes and in each analysed sample, at least 20 inclusions were analysed. Microthermometric data were obtained using a Linkam THMSG600 heating-freezing stage (temperature range $-196^{\circ} \mathrm{C}$ to $+600^{\circ} \mathrm{C}$ ) and TMS 90 controller attached to a conventional petrographic microscope. The stage was calibrated using the Synflinc set of synthetic fluid inclusions and revealed a precision of $\pm 0.1^{\circ} \mathrm{C}$ for the freezing runs and $\pm 5^{\circ} \mathrm{C}$ for temperatures near to or higher than $360^{\circ} \mathrm{C}$. Fluid inclusions with homogenization temperatures higher than $600{ }^{\circ} \mathrm{C}$ were carried out on a modified Leitz 1350 heating stage with precision of the measurement of $\pm 5^{\circ} \mathrm{C}$.

Salinities are expressed as $\mathrm{wt} \% \mathrm{NaCl}$ equivalent and were estimated from the melting temperatures of the last crystal of ice for two-phase fluid inclusions (BODNAR, 1993) and from halite dissolution temperatures for multiphase inclusions (STERNER et al., 1988). Eutectic temperatures were used to estimate the overall composition of the studied fluid inclusions by comparison with published data for different salt-water systems (SHEPHERD et al., 1985). In addition, calculation of $\mathrm{KCl}$ and possible $\mathrm{CaCl}_{2}$ contents was performed according to the phase diagrams of ROEDDER (1984) and VANKO et al. (1988) respectively.

The pressure of heterogeneous fluids has been determined using the method of sections of isochors and isotherms. Data from THIERRY et al. (1994) were used in the construction of isochors and estimate of pressures in inclusions rich in a gaseous mixture. Salinity and pressure were determined using FLINCOR software (BROWN, 1989). In cases where primary fluid inclusions trapped heterogeneous fluid, indicative of boiling conditions, it was not necessary to perform corrections of homogenization temperatures for pressure conditions.

\section{FLUID INCLUSION DATA FROM THE BUKOVIK-KADIICA}

Petrographic studies at room temperature distinguished several types of fluid inclusions: three phase (multiphase) fluid inclusions (liquid /chloride solution/ + vapour /bubble/ + one or more translucent/halite or halite+sylvite/ or opaque daughter crystals /. The selection of fluid types ideally matches the model-type III of NASH and THEODORE, 1971; see Fig. 9a; 9b; 9c; gas-rich fluid inclusions characterized by a thick liquid rim (sometimes with halite cube daughter crystal); and undersaturated two-phase, vapour-rich fluid inclusions.

Multiphase fluid inclusions, besides liquid and vapour, contain one or more solid phases (daughter crystals). The most common daughter crystal is halite determined by its cubic habit, isotropy as well as the same relief compared to quartz. Dark opaque minerals were also observed (Fig. 9d) but their identification was not possible using a transmitted light microscope. However, the triangular sharp habit indicates chalcopyrite morphology. This type of inclusion commonly shows a negative quartz crystal shape (Fig. 9c). Within some samples, three-phase types of fluid inclusion $\left(\mathrm{L}+\mathrm{V}+\mathrm{S}_{\text {opaque }}\right)$ are associated with two-phase $(\mathrm{L}+\mathrm{V})$ inclusions (Fig. 9d). Two-phase inclusions with various ratios of liquid and vapour phases have been recorded as well, but in general, V-rich inclusions are more common than L-rich ones (Fig. 9e). Fluid inclusion assemblages composed of coexisting L-rich, V-rich and multiphase inclusions suggest an entrapment from boiling fluids. Overlapping homogenization temperatures for inclusions with various phase ratios confirm the boiling environment.
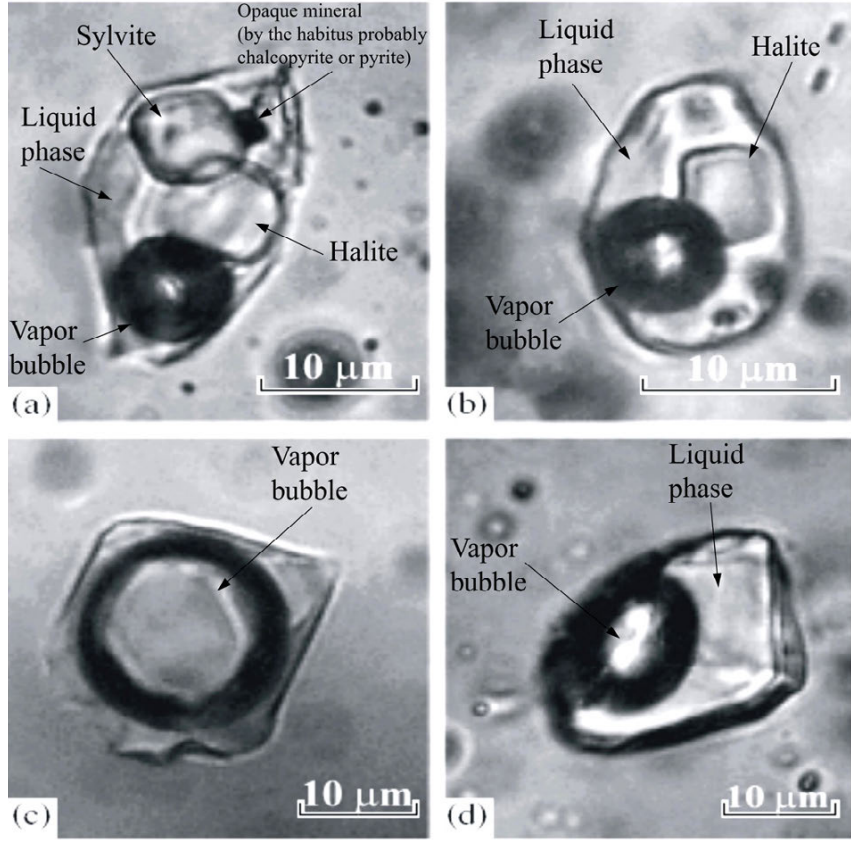

Figure 10. Types of fluid inclusions within the Bukovik-Kadiica ore deposit: (a, b) brine fluid inclusions (type I); (c) gaseous fluid inclusions (type II); (d) unsaturated (without halite) fluid inclusions (type III). The scale is $10 \mu \mathrm{m}$, Transmitted light, plain polarized light (VOLKOV et al., 2008; modified).

The studied fluid inclusions were divided into three main types according to their appearance at $25{ }^{\circ} \mathrm{C}$ (Fig. 10):

I Three phase fluid inclusions, liquid (chloride solution) + vapour (bubble) + one or more translucent (halite or halite+sylvite) or opaque daughter crystals (almost an

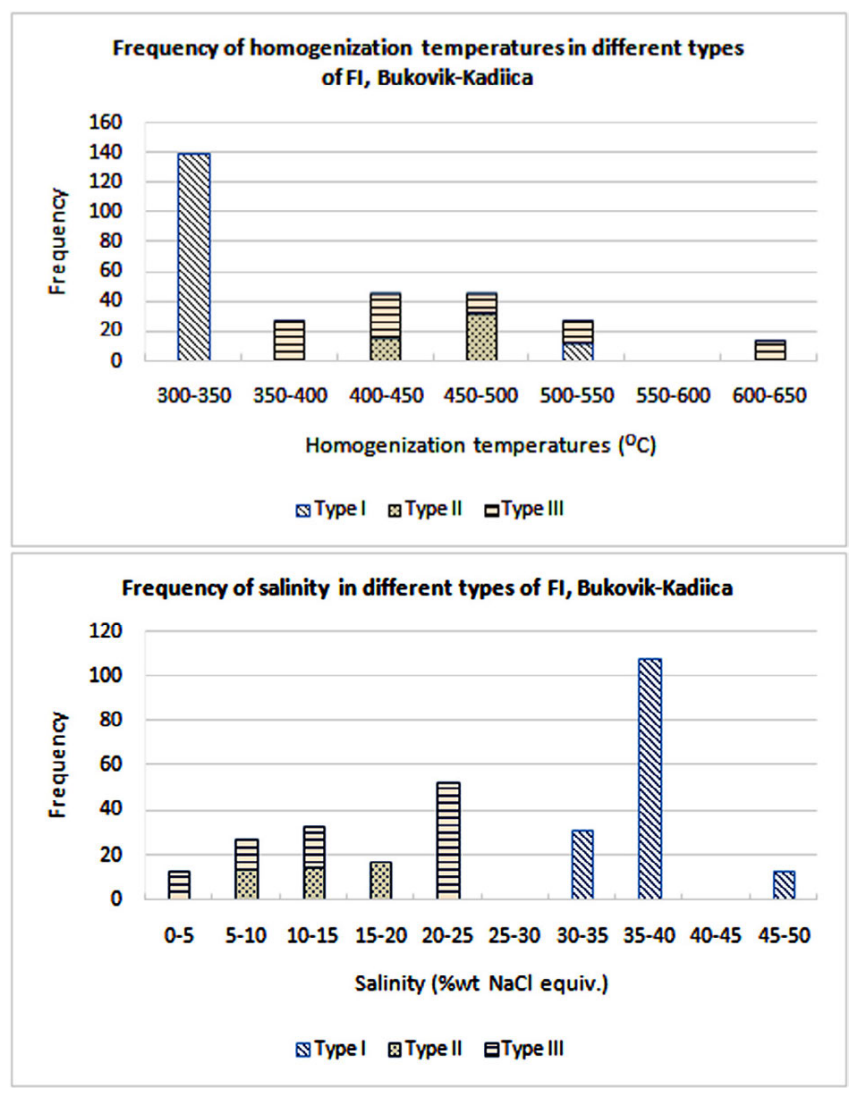

Figure 11. Histograms of homogenization temperatures and salinities of fluid inclusions in ore associated quartz samples from the Bukovik-Kadiica deposit. 


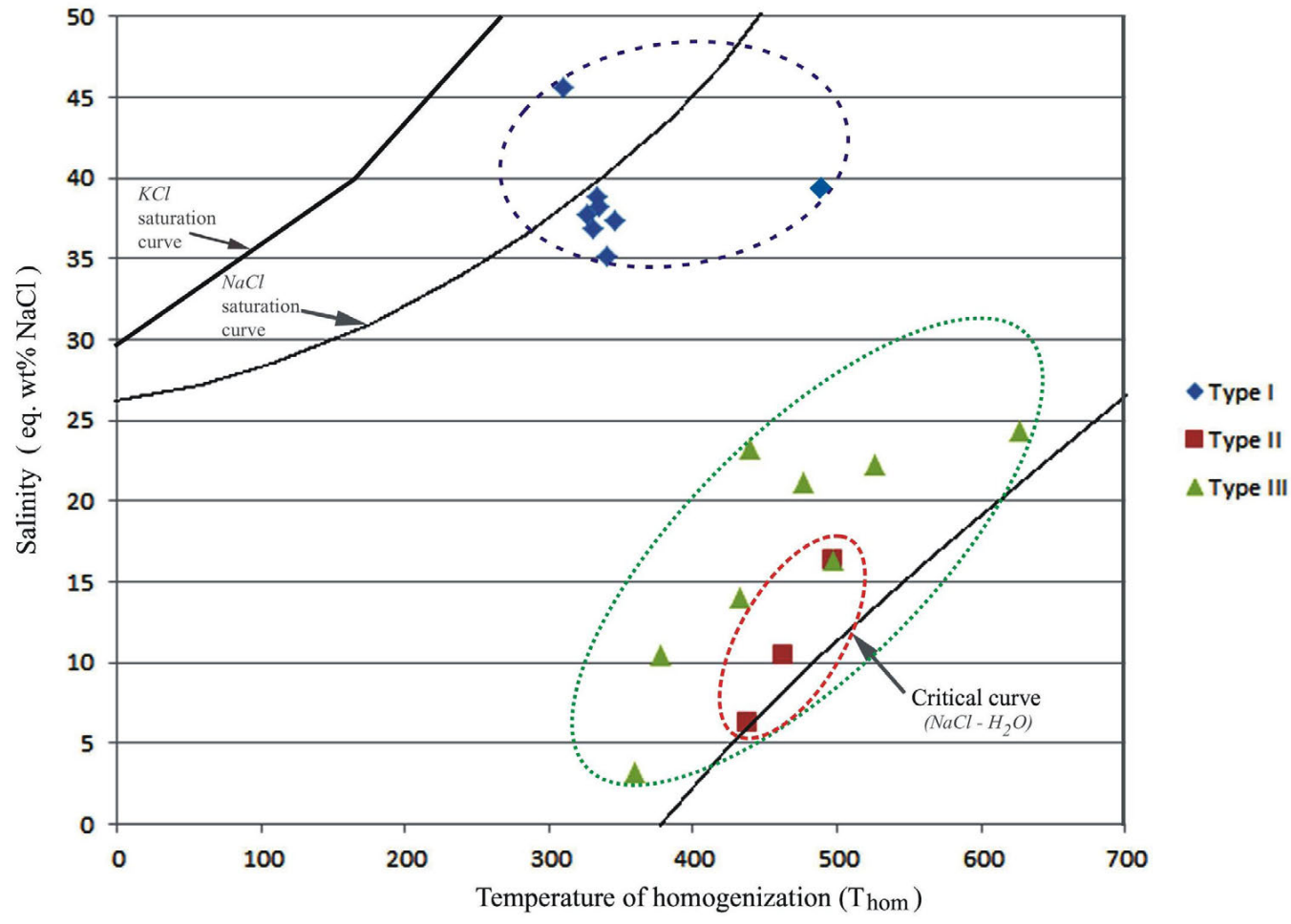

Figure 12. Summary plot of the microthermometric measurements (homogenization temperatures vs. salinities) in fluid inclusions from the Bukovik-Kadiica deposit. The saturation curve of $\mathrm{NaCl}$ and the critical curve of the $\mathrm{H}_{2} \mathrm{O}-\mathrm{NaCl}$ system are given by SOURIRAJAN \& KENNEDY, 1962 and HAAS, 1976 ; data for the saturation curve of $\mathrm{KCl}$ as summarized by POTTER et al. (1977).

ideal match to the model-type III of Nash and Theodore, 1971; see Figure 10a; 10b);

II Gas-rich fluid inclusions characterized by a thick liquid rim (sometimes with a halite cube daughter crystal; see Figure 10c); and

III Undersaturated two-phase, vapour-rich fluid inclusions (Figure 10d).

The microthermometric data are summarized in Table 1. Temperatures are given as calculated mean temperatures for each sample. Temperatures of salt dissolution are presented within brackets together with ice melting temperatures $\left(\mathrm{T}_{\text {mice }}\right)$.
The total homogenization of brine inclusions was recorded in a wide temperature interval from 501 to $310^{\circ} \mathrm{C}$ (Fig. 11a). The halite melting temperature in the range between 383 and $211^{\circ} \mathrm{C}$ corresponds to a salinity of $45.66-32.4 \mathrm{wt} \% \mathrm{NaCl}$ equiv. (Fig. 11b). The calculated fluid density varies from 1.16 to $0.90 \mathrm{~g} / \mathrm{cm}^{3}$. The pressure was calculated and estimated, in accordance to the compiled data of HAAS (1976), HAAR et al. (1984), BODNAR et al. (1985), STERNER et al. (1988), BISCHOF \& PITZER (1989), KNIGHT \& BODNAR (1989) and ATKINSON (2002), from inclusions of saturated brines ranged from 90 to 620 bar.

Vapour-dominated fluid inclusions homogenize into a vapour phase at $497-438{ }^{\circ} \mathrm{C}$ (Fig. 12). The final ice melting tem-

Table 1. Results of thermo- and cryometric studies of individual primary fluid inclusions in quartz from ore veinlets of the Bukovik-Kadica deposit, Macedonia (Thomogen temperatures are calculated mean values for each sample).

\begin{tabular}{|c|c|c|c|c|c|c|c|c|}
\hline \multirow{2}{*}{$\begin{array}{c}\text { Sample } \\
\text { No. }\end{array}$} & \multirow{2}{*}{ Type of inclusion } & \multirow{2}{*}{ No. of inclusions } & \multicolumn{3}{|c|}{${ }^{\circ} \mathrm{C}$} & \multirow{2}{*}{$\begin{array}{c}\mathrm{C}_{\text {saltsı }} \\
\mathrm{wt} \% \mathrm{NaCl} \text { equiv. }\end{array}$} & \multirow{2}{*}{ d, $\mathrm{g} / \mathrm{cm}^{3}$} & \multirow{2}{*}{ Pressure, bar } \\
\hline & & & $\mathrm{T}_{\text {homogen. }}$ & $\mathrm{T}_{\text {eut. }}$ & $\mathrm{T}_{\text {ice(halite) melt. }}$ & & & \\
\hline 1 & III & 13 & 627 & -60 & -27.4 & 24.3 & 0.58 & 925 \\
\hline 2 & III & 14 & 476 & -42 & -19.7 & 21.2 & 0.72 & 520 \\
\hline 3 & 1 & 15 & 333 & -55 & (311) & 38.9 & 1.06 & - \\
\hline 4 & I & 16 & 334 & -55 & (299) & 38.2 & 1.06 & - \\
\hline 5 & I & 21 & 346 & -55 & (289) & 37.4 & 1.04 & 100 \\
\hline 6 & I & 14 & 331 & -54 & $(283)$ & 36.9 & 1.05 & - \\
\hline 8 & I & 13 & 326 & -54 & $(294)$ & 37.7 & 1.06 & - \\
\hline 9 & 1 & 17 & 340 & -49 & (259) & 35.2 & 1.02 & 90 \\
\hline 10 & III & 12 & 439 & -48 & -24.5 & 23.2 & 0.79 & 330 \\
\hline 11 & $\|$ & 14 & 463 & -38 & -7.0 & 10.5 & - & 480 \\
\hline 12 & III & 13 & 360 & -25 & -1.9 & 3.2 & 0.60 & 200 \\
\hline 13 & III & 13 & 378 & -35 & -6.9 & 10.4 & 0.70 & 220 \\
\hline 14 & III & 18 & 432 & -36 & -10.1 & 14.0 & 0.66 & 310 \\
\hline 15 & II & 15 & 438 & -25 & -3.9 & 6.3 & - & 370 \\
\hline 17 & III & 14 & 526 & -55 & -19.9 & 22.3 & 0.65 & 660 \\
\hline 18 & $\|$ & 17 & 497 & -54 & -12.4 & 16.3 & - & 570 \\
\hline 19 & I & 17 & 328 & -55 & $(255)$ & 35.0 & 1.03 & 90 \\
\hline 20 & 1 & 12 & 501 & -55 & (317) & 39.5 & 0.90 & 490 \\
\hline
\end{tabular}




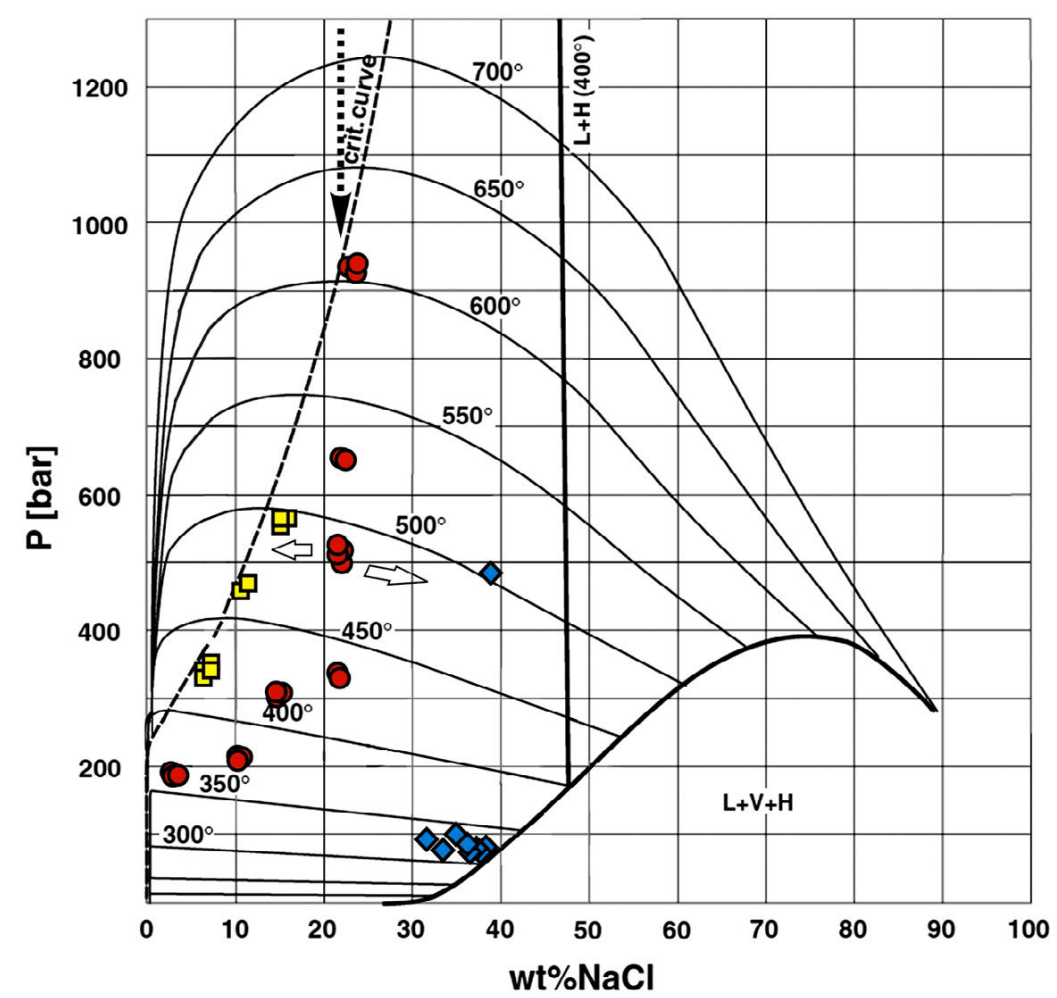

$\diamond$ FI Type I
口 FI Type II
O FI Type III

Figure 13. $\mathrm{NaCl}-\mathrm{H}_{2} \mathrm{O}$ P-T-X phase diagram (after DRIESNER \& HEINRICH, 2007; modified). The two white arrows represent stages when within system, due to change in P-T-X, other coexisting vapour and brine phases occurred other than the primary one.

peratures reflect a salinity of $16-6 \mathrm{wt} \% \mathrm{NaCl}$ equiv. These inclusions define a pressure of $370-570$ bar.

Two-phase $(\mathrm{L}+\mathrm{V})$ fluid inclusions homogenize into a liquid phase at $627-360^{\circ} \mathrm{C}$ (Fig. 12). Their eutectic temperatures vary from -60 to $-25^{\circ} \mathrm{C}$, indicating very diverse chemistry from a $\mathrm{CaCl}_{2} \pm \mathrm{MgCl}_{2}-\mathrm{NaCl}-\mathrm{H}_{2} \mathrm{O}, \mathrm{KCl}-\mathrm{NaCl}-\mathrm{H}_{2} \mathrm{O}$ to $\mathrm{NaCl}-\mathrm{H}_{2} \mathrm{O}$ system (KEEVIL, 1942; SOURIRAJAN \& KENNEDY, 1962; HELGESON, 1964; BURNHAM, 1967; ROEDDER, 1984; CANDELA \& PICCOLI, 1995; WEBSTER, 1997), which ascertains boiling in the system. The final ice melting temperature suggests a salinity of $24-3 \mathrm{wt} \% \mathrm{NaCl}$ equiv. (Fig. 12). The calculated fluid density varies from 0.58 to $0.72 \mathrm{~g} / \mathrm{cm}^{3}$.

Solid phases in some of the complex fluid inclusions were also analysed using a scanning electron microscope (SEM/EDX) (TASEV, 2010). The identity of some 'daughter' minerals is confirmed as halite (minerals with cubic habit, preliminarily determined under the optical microscope) while the other defined as sylvite (although very rare, they dissolved into liquid in the range of $75-150^{\circ} \mathrm{C}$ ), quite similar to other porphyry copper deposits worldwide (ANTHONY et al., 1984; ROEDDER, 1984; BODNAR, 1995; FAN et al., 1998; XIE et al., 2006; LI et al., 2011). The salinities of fluid inclusions containing $\mathrm{NaCl}$ and $\mathrm{KCl}$ daughter minerals (where $\mathrm{KCl}$ dissolutes as the last phase) were estimated by establishing the temperature of solution of $\mathrm{NaCl}$ and $\mathrm{KCl}$ and referring to the phase data of LINKE (1965) and to the relevant part of the system $\mathrm{NaCl}-\mathrm{KCl}-\mathrm{H}_{2} \mathrm{O}$ (ROEDDER, 1984) as well as using cotectic boundaries given by STERNER et al (1988).

\section{DISCUSSION}

Porphyry ore deposits represent the economically most important resources of $\mathrm{Cu}$ and $\mathrm{Mo}$ and host significant reserves of $\mathrm{Au}, \mathrm{Ag}$, and many other metals (SILLITOE, 2005). Porphyry deposits form at depths of approximately $1-6 \mathrm{~km}$ below the palaeosurface due to the condensation of supercritical fluids derived from a crystallizing magma reservoir in the shallow crust (e.g., SEEDORFF et al., 2005; COOKE et al., 2013). The fluid inclusion studies have been used to estimate the magmatic-hydrothermal fluid composition and P-T conditions associated with the Bukovik-Kadiica porphyry $\mathrm{Cu}$ mineralization. Although fluid inclusion data provide an exceptional insight into the physico-chemical properties of ore-forming fluids, multiple episodes of magmatic-hydrothermal fluxes associated with complex processes of mineral growth, mineral dissolution, fracturing and sealing in porphyry $\mathrm{Cu}$ systems usually result in the entrapment of numerous generations of primary and secondary fluid inclusions within annealed host mineral grains and make interpretation of the obtained data vague (COOKE et al., 2013).

Three recorded fluid inclusion types from the Bukovik-Kadiica porphyry $\mathrm{Cu}$ deposit reflect the evolution of ore-bearing fluids within the P-T-X space. The results of microthermometric studies of over 450 individual fluid inclusions (see Table 1) have shown that ore-bearing fluids contained dissolved chlorides of $\mathrm{Na}, \mathrm{Ca}$, and $\mathrm{Mg} \pm \mathrm{K}$. The earliest inclusions belong to the twophase $(\mathrm{L}+\mathrm{V})$ inclusion type. They are characterized by high homogenization temperatures and moderate salinities. Inclusions of this type are usually considered as relicts of intermediate-density primary magmatic-hydrothermal fluids that are exsolved from the crystallizing and cooling intrusive magmatic body (e.g., LANDTWING et al., 2010; REDMOND et al., 2004; SEO et al., 2012).

The earliest, two-phase, high-temperature, moderate salinity fluid inclusions are commonly overprinted with one or more generations of fluid inclusion assemblages consisting of coexisting 
high- to moderate-temperatures and low-salinity vapour-rich inclusions and multiphase high-salinity liquid-rich inclusions. This type of fluid inclusion assemblage reflects the separation of vapour from a liquid-like supercritical fluid (boiling) followed by condensation of a liquid, often of high salinity, from a supercritical fluid (e.g., BODNAR et al., 1985, HEINRICH, 2005; HEINRICH, 2007).

Late-stage fluid inclusions are mostly two-phase $(\mathrm{L}+\mathrm{V})$ lowtemperature and low-salinity inclusions of intermediate to high density. They typically homogenize to liquid, but some vapourrich inclusions may be present that homogenize to vapour. Such assemblages are indicative of boiling of low-salinity fluids (COOKE et al., 2013).

It is noted from the measurements that in all but one of the samples the halite crystal dissolves before the vapour bubble.

Generally, there are two potential causes for the formation of high-salinity fluid inclusions containing halite in porphyry copper deposits: (i) pressure reduction and phase separation from a low-salinity fluid (BURNHAM, 1979; HEDENQUIST \& LOWENSTERN, 1994; HEDENQUIST et al., 1998; ULRICH et al., 2001; KLEMM et al., 2007; LANDTWING et al., 2010); (ii) direct exsolution from the magma (ROEDDER \& COOMBS, 1967; CLINE \& BODNAR, 1991; HEDENQUIST \& LOWENSTERN, 1994, 1994; SHINOHARA, 1994; BODNAR, 1995; KAMENETSKY et al., 1999; CAMPOS et al., 2002, 2009; VEKLSER, 2004; WEBSTER \& MANDEVILLE, 2007).

As there are low-salinity vapour inclusions coexisting with high-temperature brines in the Bukovik-Kadiica porphyry copper deposit, we suggest that these saline fluids have directly exsolved by later boiling from a low-salinity fluid, rather than by direct exsolution from the magma.

The high homogenization temperatures and salinities of the saturated fluid inclusions indicate the initial existence of a dense brine, single phase fluid $\left(0.90-1.16 \mathrm{~g} / \mathrm{cm}^{3}\right.$, Table 1$)$, at magmatic temperatures (ROEDDER, 1992; SANTANA et al., 2011). Coexistence of vapour like (low salinity) + two phase medium salinity + very rare halite bearing fluid inclusion at the temperature between 400 and $500^{\circ} \mathrm{C}$, however, is much more convincing for the boiling and separation of the original early high temperature phase into a heterogenous system.

After physical separation from dense brine in fractured porphyry stock (due to immiscibility), only the less viscous and more buoyant vapour phase may rise to the epithermal environment (HENLEY \& McNABB, 1978; HEINRICH et al., 1999). The coexistence of vapour-rich and high-salinity inclusions that homogenize within the same temperature range (Table 1) suggests that these fluids represent two immiscible fluids that evolved from the dense magmatic fluid (SANTANA et al., 2011). Density and compositional differences between the saline and low-density fluids affects the physical and chemical behaviour of these fluids in the porphyry system, in turn affecting the distribution of the precipitated minerals.

The present study shows that just slightly above $600^{\circ} \mathrm{C}$ and at a pressure above $900 \mathrm{bar}(90 \mathrm{MPa})$, the first exsolved magmatic fluid must have been a two-phase medium-salinity fluid, L+V (Fig. 13), followed by a gradual salinity decrease during magma crystallization at low temperature, which is very similar to the data given for some other deposits (KILINC \& BURNHAM, 1972; CLINE \& BODNAR, 1991; SHINOHARA, 1994; CANDELA \& PICCOLI, 1995; CLINE, 1995; FOURNIER, 1999; CLINE, 2003; HARRIS et al., 2005; WEBSTER AND MANDEVILLE, 2007).
Fluid exsolution from hydrous magma plays an important role in mineralization (HEDENQUIST \& LOWENSTERN, 1994; WEBSTER, 1997; AUDÉTAT \& PETTKE, 2003; IMAI, 2005; KAMENETSKY \& KAMENETSKY, 2010). Notably early fluid exsolution is favourable for economic mineralization because it facilitates the transfer of ore-forming elements into the fluid (CANDELA \& HOLLAND, 1986; ZHANG et al., 2001; LI et al., 2006). Here it is apparent that at intermediate and low pressures $(<60 \mathrm{MPa})$, and temperatures lower than $500{ }^{\circ} \mathrm{C}$, initial low-salinity magmatic fluids gradually increased in salinity during magma crystallization as the solubility decreased with falling temperature and daughter minerals (halite, sylvite, etc.) may have nucleated. Immiscible fluids must have formed with compositions corresponding to the aforementioned Type I, Type II, and Type III. These fluids correspond to the vapour and brine phases, respectively, which formed as a result of boiling. This fluid evolution pattern is quite similar to that proposed by WILLIAMSJONES \& HEINRICH (2005) for porphyry copper deposits, and furthermore the obtained P-T-X values fit quite well into the common range for porphyry deposits elsewhere (WILKINSON, 2001).

Vapour-rich inclusions are interpreted as being coeval with multiphase brine inclusions or abundant liquid-rich inclusions, indicating that the ore-forming fluid was boiling (LI et al., 2007). The fluid inclusion study demonstrates that at some point Kadiica has experienced boiling of hydrothermal fluids. The coexistence of vapour-only and vapour-rich as well as high-salinity inclusions within the same fluid inclusion associations is considered evidence of boiling (HEDENQUIST \& LOWENSTERN, 1994; HEINRICH, 2005), similar to descriptions form porphyry systems elsewhere (SOURIRAJAN \& KENNEDY, 1962; ROEDDER, 1979; HEDENQUIST \& LOWENSTERN, 1994; GAMMONS \& WILLIAMS-JONES, 1997; HEINRICH, 2005).

Variations in salinity indicate boiling processes, which probably led to the deposition of certain metals (GRANCEA et al., 2002). Salinity variations could also be partially attributed to the existence of explosive volcanic stages (confirmed by determined phreatomagmatic breccia at Bukovik-Kadiica; WESTRA, 2005), the fracturing of adjacent rock complexes, and similar processes.

The appearance of high-salinity inclusions, beside low-salinity ones, indicates that during particular geological periods the Bukovik-Kadiica magmatic-hydrothermal system must have generated brine fluids from deeper reservoirs (not excluding some of the afore-mentioned possibilities: salinity increase as the system evolved; boiling at certain stages or some meteoric water overprint). High-salinity fluids (fluid inclusions up to $46 \mathrm{wt} \% \mathrm{NaCl}$ equiv.) probably played an important role in the polymetallic mineralization of the Bukovik-Kadiica deposit, since chloride complexes are an effective mode of metal transport (BARNES, 1979). The displayed data are very common in porphyry copper deposits. Here we would like to point out, that although some fluid inclusions have shown that $\mathrm{Cu}$ commonly occurs at higher concentrations in vapour-type inclusions than in coexisting brine inclusions, the transport of certain elements $(\mathrm{Cu}, \mathrm{Au})$ or compounds in low-density fluids that preferentially partitioned into the vapour phase should be excluded since recent studies confirmed that $\mathrm{Cu}$ concentrations in quartz-hosted fluid inclusions from magmatic-hydrothermal ore deposits do not represent pristine concentrations in the trapped fluids, but are modified by postentrapment diffusional exchange through the host quartz, where quartz-hosted fluid inclusions can diffusively loose or gain $\mathrm{Cu}$ 
after entrapment (LERCHBAUMER \& AUDÉTAT, 2012; SEO \& HEINRICH, 2013).

The early high-temperature fluid must have already been saturated in copper (chalcopyrite daughter crystals in FI), so that $\mathrm{Cu}$ precipitation probably occurred before the onset of the main alteration and mineralization event, which could explain the low copper contents in the hypogene mineralization of the BukovikKadiica prospect.

The abundance of solid phases both daughter (halite and occasionally sylvite) and opaque phases (ore minerals) suggest that they were part of the original fluid, which must have been rich in ore-forming elements (LI et al., 2011). The occasional presence of daughter minerals, notably chalcopyrite, in Type III undersaturated fluid inclusions, indicates that the early derived aqueous fluid characterized by low-moderate salinity, moderate $\mathrm{CO}_{2}$ contents, were $\mathrm{Cu}$ rich and responsible for the transport of $\mathrm{Cu}, \mathrm{Fe}$, and $\mathrm{S} \pm \mathrm{Au}$, as suggested elsewhere (GONZALEZ-PATIDA \& LEVRESSE, 2003; REDMOND et al., 2004; RUSK et al., 2008; RUSK et al., 2011). The presence of alunite suggests that one part of the sampled area is located within the outer zones of mineralization, associated with argillic alteration, which is known to occur along the margin in a porphyry system (GUILBERT \& PARK, 1996), and is confirmed for the Bukovik-Kadiica deposit (TASEV, 2010).

The large homogenization temperature range of $310-627^{\circ} \mathrm{C}$ is in accordance with a homogenization temperature range from 250 up to $550^{\circ} \mathrm{C}$ (commonly boiling) which is characteristic for numerous porphyry copper deposits (MOORE \& NASH, 1974; GUSTAFSON \& HUNT, 1975; CHIVAS \& WILKINS, 1977; MOORE \& MOORE, 1979; AHMAD \& ROSE, 1980; BEANE \& TITLEY, 1981; KLEMM et al., 2007; KLEMM et al., 2008). Boiling curves for $\mathrm{NaCl}$ solutions (SHEPHERD et al., 1985) and their relationship to Th and depth, were used to calculate the palaeodepth of mineralization $(\sim 800 \mathrm{~m})$ that suggests pressures typically between 300 and 1200 bar, which corresponds to a lithostatic load cover of 1-4 km (ROEDDER, 1984; Alumbrera: ULRICH et al., 2001; Bingham Canyon: REDMOND et al., 2004). However, several episodes of possible boiling effects, the system with wide fluctuation of pressure, even volcanic extrusion and presence of phreato-magmatic breccias etc., assured us that is not convenient to judge the palaeodepth.

Relatively high metal concentrations (from a few parts per million up to weight percentages) have been determined in vapour-rich inclusions formed under pressures of 200 to 1000 bars and temperatures of $400-650{ }^{\circ} \mathrm{C}$ (WILLIAMS-JONES \& HEINRICH, 2005). High copper concentrations, in volcanic vapour/gas, typically in the percentage range have been estimated from the size of chalcopyrite "daughter" crystals in fluid inclusions (ROEDDER, 1971; EASTOE, 1978; HENLEY \& McNABB, 1978).

Type III inclusions, with occasional small daughter opaque mineral (chalcopyrite) occurred at levels characterized by potassic alteration (its transitional parts to phyllic alteration). Two phase, liquid-rich inclusions occurred in the propylitic envelopelike alteration and some peripheral parts of the argillic alteration. Central parts of the phyllic alteration were dominated by type II inclusions while going up to lower temperatures and pressures, toward the upper parts of the phyllic and lower parts of the argillic alteration, type I inclusions prevailed. Although optional and despite the sometimes precluding nature of fluid inclusions in the interpretation of the origin of fluids (due to multistage trapping, overprinting etc.), these findings were consistent with those of BEANE \& BODNAR (1995) and RUSK et al. (2008).

\section{CONCLUSIONS}

The extension, quantity, and quality, of the relatively newly discovered porphyry copper deposit of Bukovik-Kadiica, were defined at the beginning of 2013 after completion of detailed geological exploration by the Kadiica Metal company. Porphyry copper mineralization is of the stockwork type within the brecciated dacite-andesite stock which intruded Palaeozoic schists of the Serbo-Macedonian Massif. The major ore mineral within the Kadiica deposit is chalcocite, while within the mineral assemblage covellite, bornite, enargite, emplectite, pyrite, pyrrhotite, and chalcopyrite were also determined. These minerals are now mainly concentrated in the cementation zones. Alteration minerals, which dominate in the hydrothermally altered dacite breccia, are quartz, sericite, calcite, chlorite, kaolinite, illite and alunite with progressive silicification being the most dominant.

Fluid inclusions in quartz veins of the brecciated dacite-andesite volcanic rocks have shown that hydrothermal solutions consisted mainly of chlorides of $\mathrm{Na}, \mathrm{Ca}, \mathrm{K}$ and $\mathrm{Mg}$ with a wide range of salinity of $3-45 \mathrm{wt} \%$ equiv. The homogenization temperatures are within the range of 310 to $627^{\circ} \mathrm{C}$, which implies the development of primary sulphide associations at medium and high temperatures. The correlation of such high temperatures with the calculated pressures suggests that the studied fluids are related to magmatic fluids, which later transformed into ore-bearing hydrothermal fluids of pulsative character.

The first exsolved magmatic fluids (above $600-610^{\circ} \mathrm{C}$ and pressure above 900 bar) were two-phase and medium-salinity fluids, followed by a gradual decrease in salinity during magma crystallization at intermediate and low pressures $(<90 \mathrm{MPa})$, as well as a decrease in temperatures to below $500{ }^{\circ} \mathrm{C}$. Initial lowsalinity magmatic fluids gradully increased in salinity with magma crystallization as the solubility of solutes also decreased with falling temperature and separate crystals of daughter minerals could nucleate and grow. In this manner three immiscible fluids formed with compositions corresponding to the aforementioned Type I, Type II, and Type III. The appearance of high-salinity inclusions, beside existing low-salinity ones, indicates that in particular geological periods of the existence of the BukovikKadiica magmatic-hydrothermal system there was a yield of brine fluids from deeper reservoirs although some other possibilities should not be excluded (salinity increase of the magmatic volatile phase as the system evolved; boiling only during certain stages or that there could be some meteoric water overprint).

\section{ACKNOWLEDGEMENT}

We greatly acknowledge the comments of the anonymous reviewer(s).

\section{REFERENCES}

AHMAD, S.N. \& ROSE, A.W. (1980): Fluid inclusions in porphyry and skarn ore at Santa Rita, New Mexico.- Econ. Geol., 75, 229-250. doi: 10.2113/gsecongeo.75.2.229

ALEXANDROV, M. \& BOMBOL, D. (2007): Izveštaj od istražuvanjata vo periodot 2002-2006 na koncesijata Kadiica-Pehčevo [Report of explorations in the period 2002-2006 of the concession Kadiica-Pehcevo - in Macedonian].- PHELPS DODGE EXPLORATION CORPORATION, Phoenix, Arizona, USA, 30 p.

ANTHONY, E.Y., REYNOLDS, T.J. \& BEANE, R.E. (1984): Identification of daughter minerals in fluid inclusions using scanning electron microscopy and energy dispersive analysis.-Amer. Mineral., 69, 1053-1057.

ANTIĆ, M., PEYTCHEVA, I., VON QUADT, A., KOUNOV, A., TRIVIĆ, B., SERAFIMOVSKI, T., TASEV, G., GERDJIKOV, I. \& WETZEL, A. (2016): Pre-Alpine evolution of a segment of the North-Gondwanan margin: Geochronological and geochemical evidence from the central Serbo-Macedonian Massif.- Gondwana Resear., 36, 523-544, doi: 10.1016/j.gr.2015.07.020 
ARSOVSKI, M. \& IVANOV, T. (1977): Neotectonics magmatism and metallogeny on the territory of Yugoslavia.- Metallogeny and platetectonics in the NE Mediterranean, Belgrade, 471-482.

ATKINSON, A.B.JR. (2002): A Model for the PTX Properties of H2O-NaCl.- MSc Thesis, Faculty of Virginia Polytechnic Institute and State University, USA (Comm: Robert J. Bodnar, Cahit Coruh and Christine Anderson-Cook), 126 p.

AUDÉTAT, A. \& PETTKE, T. (2003): The magmatic-hydrothermal evolution of two barren granites: A melt and fluid inclusion study of the Rito del Medio and Canada Pinabete plutons in northern New Mexico (USA).- Geoch. et Cosmoch. Acta, 67, 97-121. doi: 10.1016/S0016-7037(02)01049-9

BARNES, H.L. (1979): Solubilities of ore minerals.- In: BARNES H.L. (ed): Geochemistry of hydrothermal ore deposits. Wiley, New York, 404-460.

BEANE, R.E. \& TITLEY, S.R. (1981). Porphyry copper deposits: Part II. Hydrothermal Alteration and Mineralization.- Econ. geol., $75^{\text {th }}$ Anniversary Vol. (eds. SKINNER, J.B.), 235-269.

BEANE, R.E. \& BODNAR, R.J. (1995): Hydrothermal fluids and hydrothermal alteration in porphyry copper deposits.- In: PIERCE, F.W. \& BOHM, J.G. (eds): Porphyry Copper Deposits of the American Cordillera. Ariz. Geol. Soc. Dig., 20, 83-93.

BISCHOFF, J.L. \& PITZER, K.S. (1989): Liquid-vapor relations for the system $\mathrm{NaCl}-\mathrm{H}_{2} \mathrm{O}$ : summery of the PTX surface from $300^{\circ}$ to $500^{\circ} \mathrm{C}$.- Amer. J. Sci., 289, 217-248.

BLUNDY, J., MAVROGENES, J., TATTITCH, B., SPARKS, S. \& GILMER, A. (2015): Generation of porphyry copper deposits by gas-brine reaction in volcanic arcs.Nature Geoscience, 8/3, 235-240. doi: 10.1038/ngeo2351

BODNAR, R.J. \& VITYK, M.O. (1994): Interpretation of microterhrmometric data for $\mathrm{H}_{2} \mathrm{O}-\mathrm{NaCl}$ fluid inclusions.- In: DE VIVO, B. \& FREZZOTTI, M.L. (eds): Fluid inclusions in minerals: methods and applications. Pontignano-Siena, 117-130.

BODNAR, R.J., BURNHAM, C.W. \& STERNER, S.M. (1985): Synthetic fluid inclusions in natural quartz. III. Determination of phase equilibrium properties in the system $\mathrm{H}_{2} \mathrm{O}-\mathrm{NaCl}$ to $1000 \mathrm{C}$ and 1500 bars.- Geoch. et Cosmoch. Acta, 49/9, 1861-1873. doi: 10.1016/0016-7037(85)90081-X

BODNAR, R.J. (1995): Fluid-inclusion evidence for a magmatic source of metals in porphyry copper deposits.- In: THOMPSON, J.F.H. (ed.): Magmas, Fluids and Ore Deposits. Mineral Assoc Can Short Course Ser, 23, 139-152.

BODNAR, R.J. (1993): Revised equation and table for determining the freezing point depression of $\mathrm{H}_{2} \mathrm{O}-\mathrm{NaCl}$ solutions.- Geoch. and Cosmoch. Acta, 57, 683-684. doi: 10.1016/0016-7037(93)90378-A

BOEV, B., JANKOVIĆ, S. \& SERAFIMOVSKI, T. (1997): Magmatism and Tertiary Mineralization of the Kozuf Metallogenetic District, the Republic of Macedonia with Particular Reference to the Alshar deposit.- Spec. Publ., No.5., Faculty of Mining and Geology-Štip, p 262.

BOEV, B. \& YANEV, Y. (2001): Tertiary magmatism within the Republic of Macedonia: a review.-Acta Vulcanol., 13/1-2, 57-71.

BOGOEVSKI, K. (1965): Metalogenija povezana sa Tercijernim magmatizmom u oblasti Osogovo-Besna Kobila [Metallogeny related to Tertiary magmatism in the Osogovo-Besna Kobila area - in Serbian].- PhD, Faculty of Mining and Geology, University in Belgrade, Serbia, 243 p.

BOYANOV, I., DABOVSKI, C., GOCEV, P., HARKOVSKA, A., KOSTADINOV, V., TZANKOV, T.Z. \& ZAGORCEV, I. (1989): A new view of the Alpine tectonic evolution of Bulgaria.- Geol. Rhod., 1, 107-121.

BRIMHALL, G.H. JR. (1979): Lithologic determinations of mass transfer mechanism of multiple-stage porphyry copper mineralization at Butte, Montana. Vein formation by hypogene leaching and enrichment of potassium-silicate protore.- Econ. Geol., 74, 556-589.

BROWN, P. (1989): FLINCOR: a computer program for the reduction and investigation of fluid inclusion data.- Amer. Mineral., 74, 1390-1393.

BURCHFIEL, B.C., NAKOV, R., DUMURDZANOV, N., PAPANIKOLAOU, D., TZANKOV, T., SERAFIMOVSKI, T., KING, R.W., KOTZEV, V., TODOSOV, A. \& NURCE, B. (2008A): Evolution and dynamics of the Cenozoic Tectonics of the South Balkan extensional system.- Geosphere, 4/6, 919-938.

BURCHFIEL, B.C., KING, W.R., NAKOV, R., TZANKOV, T., DUMURDZANOV, N., SERAFIMOVSKI, T., TODOSOV, A. \& NURCE, B. (2008B): Patterns of Cenozoic Extensional Tectonism in the South Balkan Extensional System.- In: HUSEBYE, E. S. (ed.): Earthquake Monitoring and Seismic JHazard Mitigation in Balkan Countries. Springer, 3-18. doi: 10.1007/978-1-4020-6815-7 1

BURNHAM, C.W. (1967): Hydrothermal fluids at the magmatic stage.- In:BARNES, H. L. (ed.): Geochemistry of Hydrothermal Ore Deposits. New York: John Wiley, $34-76$.

BURNHAM, C.W. (1979): Magmas and hydrothermal fluids.- In: BARNES, H.L. (ed.): Geochemistry of hydrothermal ore deposits, $2^{\text {nd }}$ ed.: New York, Wiley and Sons, 71-136.

CAMPOS, E., TOURET, J.L.R., NIKOGOSIAN, I. \& DELGADO, J. (2002): Overheated, Cu-bearing magmas in the Zaldívar porphyry-Cu deposit, Northern Chile: Geodynamic consequences.- Tectonophysics, 345, 229-251.
CAMPOS, E., WIJBRANS, J. \& ANDRIESSEN, A.M.P. (2009): New thermochronologic constraints on the evolution of the Zaldívar porphyry copper deposit, Northern Chile. - Min. Dep., 44/3, 329-342.

CANDELA, P.A. \& HOLLAND, H.D. (1986): A mass-transfer model for copper and molybdenum in magmatic hydrothermal systems-the origin of porphyry-type oredeposits.- Econ. Geol., 81, 1-19.

CANDELA, P.A. \& PICCOLI, P.M. (1995): Model ore-metal partitioning from melts into vapor and vapor/brine mixtures.- In: THOMPSON, J.F.H. (ed.): Magmas, Fluids, and Ore Deposits. Mineralogical Association of Canada Short Course Series, 23, 101-127.

CANDELA, P.A. \& PICCOLI, P.M. (2005): Magmatic processes in the development of porphyry-type ore systems. Economic Geolology, One Hundred Anniversary Volume: $25-38$.

CHIVAS, A.R. \& WILKINS, W.T. (1977): Fluid inclusion studies in relation to hydrothermal alteration and mineralization at the Koloula porphyry copper prospect, Guadalcanal.- Econ. Geol., 72, 153-169. doi: 10.2113/gsecongeo.72.2.153

CLINE, J.S. \& BODNAR, R.J. (1991): Can economic porphyry copper mineralization be generated by a typical Calc-Alkaline melt?- J. Geophys. Resear., 5, 8113-8126. doi: 10.1029/91JB00053

CLINE, J.S. (1995): Genesis of porphyry copper deposits: The behaviour of water, chloride and copper in crystallizing melts.-Ariz. Geol. Soc. Digest, 20, 69-82.

CLINE, J.S. (2003): How to concentrate copper.- Science, 302, 2075-2076.

COOKE, D.R., \& WILKINSON, J.J. (2014): Geochemistry of Porphyry Deposits.- Treatise on Geochemistry, Second Editionth edn. Elsevier, Oxford, 357-381. doi: 10.1016/B978-0-08-095975-7.01116-5

DABOVSKI, C., BOYANOV, I., KHRISCHEV, K.H., NIKOLOV, T., SAPOUNOV, I., YANEV, Y. \& ZAGORCHEV, I. (2002): Structure and Alpine evolution of Bulgaria.- Geol. Balc., 32/2-4, 9-15.

DIMITRIJEVIĆ, M.D. (1959): Basic characteristics of the column of the Serbo-Macedonian Mass.-Abstracts of the First symposium of the Serbian Geological Society, Belgrade.

DIMITRIJEVIC, M. (1995): Geology of Yugoslavia.- Geoinstitute, Belgrade, 205 p.

DRIESNER, T. \& HEINRICH, C.A. (2007): The system $\mathrm{H}_{2} \mathrm{O}-\mathrm{NaCl}$. I. Correlation formulae for phase relations in temperature-pressure-composition space from 0 to $1,000^{\circ} \mathrm{C}, 0$ to 5000 bar, and 0 to $1 \mathrm{XNaCl}$.- Geoch. et Cosmoch. Acta, 71, 4880-4901.

DURMURDZANOV, N., SERAFIMOVSKI, T. \& BURCHFIEL, B.C. (2004): Evolution of the Neogene-Pleistocene basins of Macedonia.- Geological Society of America, Digital Map and Chart Series MC01, 20 p.

DURMURDZANOV, N., SERAFIMOVSKI, T. \& BURCHFIEL, B.C., (2005): Cenozoic tectonics of Macedonia and its relation to the South Balkan extensional regime.- Geosphere, 1/1, 1-22.

DUZELKOVSKI, D. (1960): Geološki sostav na terenot Delčevo-Pehčevo (Planina Vlaina) [Geological composition of the terrain Delčevo-Pehčevo (Vlaina Mountain) - in Macedonian].- Papers of the Geol. Survey of the Republic of Macedonia, Skopje, 7, 66-82.

EASTOE, C.J. (1978): Fluid inclusion study of the Panguna porphyry copper deposit, Bougainville, Papua-New-Guinea.- Econ. Geol., 73, 721-748. doi: 10.2113/gsecongeo.73.5.721

FAN, H.R., XIE, Y.H. \& WANG, Y.L. (1998): Determining daughter minerals in fluid inclusions under scanning electron microscope.- Geol. Sci. and Techn. Inform. 17(sup.), 111-117.

FOURNIER, R. (1999): Hydrothermal processes related to movement of fluid from plastic into brittle rock in the magmatic-epithermal environment.- Econ. Geol., 94, $1193-1212$.

GAMMONS, C.H. \& WILLIAMS-JONES, A.E. (1997): Chemical mobility of gold in the porphyry-epithermal environment.- Econ. Geol., 92, 45-59.

GJORGJEVIC, V., KARAMATA, S. \& GJORGJEVIC, P. (1975): Proučavanje hidrotermalnih alteracija lokalnosti Borov Dol [Study of hydrothermal alterations at the Borov Dol locality - in Serbian].- Faculty of Mining and Geology, Laboratory for petrology, Belgrade, $30 \mathrm{p}$.

GOLDSTEIN, R.H. \& REYNOLDS, T.J. (1994): Systematics of fluid inclusions in diagenetic minerals.- SEPM Short Course 31. Soc. for Sediment. Geol., 199 p. doi: $10.2110 /$ scn. 94.31

GONZALEZ-PATIDA, E. \& LEVRESSE, G. (2003): Fluid inclusion evolution at the La Verde porphyry copper deposit, Michocan, Mexico.- J. Geoch. Explor., 78/79, 623-626.

GRAF, J. (2001): Alpine tectonics in western Bulgaria: Cretaceous compression of the Kraiste region and Cenozoic exhumation of the crystalline Osogovo-Lisec Complex.- PhD ETH No 14'238, Zurich, Switzerland, 197 p.

GRANCEA, L., BAILLY, L., LEROY, J., BANKS, D., MARCOUX, E., MILÉSI, J.P., CUNEY, M., ANDRÉ, A.S., ISTVAN, D. \& FABRE, C. (2002): Fluid evolution in the Baia Mare epithermal gold/polymetallic district, Inner Carpathians, Romania.- Min. Dep. 37/6-7, 630-647. doi: 10.1007/s00126-002-0276-5

GRUBIĆ, A. (1980): Yugoslavia: Outline of Yugoslavian geology.- $26^{\text {th }}$ Internat. Geological Congress, Paris, 615, 5-49. 
GUILBERT, J.M. \& PARK, C.F. (1996): The Geology of Ore Deposits.- Fifth Printing, W.H Freeman and Company, United States of America, 985 p.

GUSTAFSON, L.B. \& HUNT, J.P. (1975): The porphyry copper deposit at El Salvador, Chile.- Econ. Geol., 70, 857-912. doi: 10.2113/gsecongeo.70.5.857

HAAR, L., GALLAGHER, T.S. \& KELL, G.S. (1984): NBS/NRS Steam Tables: Thermodynamic and transport properties and computer programs for vapor and liquid states in SI units.- Hemisphere, Washington, DC, $120 \mathrm{p}$

HAAS, J. (1976): Physical properties of the coexisting phases and thermochemical properties of the $\mathrm{H}_{2} \mathrm{O}$ component in boiling $\mathrm{NaCl}$ solution (Preliminary steam tables for $\mathrm{NaCl}$ solution).- US Geol. Surv. Bull., 1421-A, 1-71.

HADŽI-PETRUSEV, B. (1985): Извештај за деталните истражувања на бакар на Буковик-Кадиица, Берово [Report of detailed copper explorations at the Bukov$i k$-Kadiica, Berovo - in Macedonian].- Geol. Surv. Maced., 78 p.

HARKOVSKA, A. (1984): Tertiary magmotectonic zones in southwest Bulgaria.- In: VOZAR, J. (ed.): Magmatism of the molasse-forming epoch and its relation to endogenous mineralization: Bratislava, Geologicky ustav Dioyza Stura, 9-34

HARKOVSKA, A., YANEV, Y. \& MARCHEV, P. (1989): General features of the Paleogene orogenic magmatism in Bulgaria.- Geol. Balc., 19/ 1, 37-72.

HARRIS, A.C., GOLDING, S.D. \& WHITE, N.C. (2005): The genesis of Bajo de la Alumbrera deposit: stable isotope evidence for a porphyry-related hydrothermal system dominated by magmatic aqueous fluids.- Econ. Geol., 101, 71-94.

HEDENQUIST, J.W. \& LOWENSTERN, J.B. (1994): The role of magmas in the formation of hydrothermal ore deposits.-Nature, 370,519-527. doi: 10.1038/370519a0

HEDENQUIST, J.W., ARRIBAS, A.J. \& REYNOLDS, T.J. (1998): Evolution of an intrusion-centered hydrothermal system: Far Southeast-Lapanto porphyry and epithermal $\mathrm{Cu}-\mathrm{Au}$ deposits, Philippines.- Econ. Geol., 93, 373-404. doi: 10.2113/ gsecongeo.93.4.373

HEINRICH, C.A. (2005): The physical and chemical evolution of low salinity magmatic fluids at the porphyry to epithermal transition: a thermodynamic study.- Min. Dep., 39, 864-889. doi: 10.1007/s00126-004-0461-9

HEINRICH, C.A. (2007): Fluid-fluid interactions in magmatic-hydrothermal ore formation.- Reviews Mineral. and Geoch., 65, 363-87. doi: 10.2138/rmg.2007.65.11

HEINRICH, C.A., GÜNTER, D., AUDÉTAT, A., ULRICH, T. \& FRISCHKNECHT, R., (1999): Metal fractionation between magmatic brine and vapour, determined by microanalysis of fluid inclusions.- Geology 27, 755-758.

HEINRICH, C.A., HALTER, W., LANDTWING, M.R. \& PETTKE, T. (2005): The formation of economic porphyry copper (-gold) deposits: constraints from microanalysis of fluid and melt inclusions.- In: MCDONALD, I., BOYCE, A.J., BUTLER, I.B., HERRINGTON, R.J. \& POLYA, D.A. (eds): Mineral Deposits and Earth Evolution. Geological Society, London, Special Publications, 248, 247-263. doi: 10.1144/GSL.SP.2005.248.01.13

HELGESON, H.C. (1964): Complexing and Hydrothermal Ore Deposition.--New York, Pergamon, $136 \mathrm{p}$.

HENLEY, R.W. \& MCNABB, A. (1978): Magmatic vapor plumes and groundwater interaction in porphyry copper emplacement.- Econ. Geol., 73, 1-20.

IMAI, A. (2005): Evolution of hydrothermal system at the Dizon porphyry Cu-Au deposit, Zambales, Philippines.-Resource geol., 55, 73-90. doi: 10.1111/j.1751-3928. 2005.tb00230.x

IVANOV, T. \& DENKOVSKI, DJ. (1980): Hydrothermal alterations in the Plavica-Zlatica porphyry copper deposit within the Kratovo-Zletovo volcanic area.- Symposia Alteration of rocks and minerals, 100 years of geological school and science in Serbia, Belgrade, $291 \mathrm{p}$

IVESON, A.A., WEBSTER, J.D., ROWE, M. C., \& NEILL, O.K. (2016): Magmatichydrothermal fluids and volatile metals in the Spirit Lake pluton and Margaret Cu-Mo porphyry system, SW Washington, USA.- Contrib. Mineral. and Petrol., $171 / 3,1-32$

JANKOVIĆ, S. (1977): The copper deposits and geotectonic setting of the Tethyan EuroAsian metallogenetic belt.- Mineral. Dep., 12/1, 37-47.

JANKOVIĆ, S. (1997): The Carpatho-Balkanides and adjacent area: a sector of the Tethyan Eurasian metallogenetic belt.- Min. Dep., 32/5, 426-433. doi: 10.1007/ s001260050110

JANKOVIĆ, S. \& PETKOVIC, M. (1974): Metallogeny and Concepts of the Geotectonic Development of Yugoslavia.- Metallogeny and Concepts of the Geotectonic Development of Yugoslavia, Faculty of Mining and Geology-Belgrade, 443-477.

JANKOVIĆ, S., PETKOVIĆ, M., TOMSON, I.N. \& KRAVCOV, V. (1980): Porphyry Copper deposits in the Serbo-Macedonian province, southeastern Europe.- In: JANKOVIĆ, S. \& SILLITOE, R.H.( eds): European Copper Desposits, SGA Special publication No. 1, UNESCO-IGCP Projects No. 169 and 60, 96-102.

JANKOVIĆ, S. \& SERAFIMOVSKI, T. (1997): Specific Features of Mineralization Related to Different Tectonic Enviroments in the Serbo-Macedonian Metallogenic Province.-Symposia-Annual Meeting, Proceedings, Dojran, 285-286.

JANKOVIĆ, S., SERAFIMOVSKI, T., JELENKOVIC, R. \& CIFLIGANEC, V. (1997): Metallogeny of the Vardar zone and Serbo-Macedonian Mass.-Symposium-Annual Meeting, Proceeding, Dojran, 29-67.

KAMENETSKY, V.S., WOLFE, R.C., EGGINS, S.M., MERNAGH, T.P. \& BASTRAKOV, .E (1999): Volatile exsolution at the Dinkidi Cu-Au porphyry deposit,
Philippines: A melt-inclusion record of the initial ore-forming process.- Geology, 27, 691-694. doi: 10.1130/0091-7613(1999)027\%3C0691:VEATDC\%3E2.3.CO;2

KAMENETSKY, V.S. \& KAMENETSKY, M.B. (2010): Magmatic fluids immiscible with silicate melts: examples from inclusions in phenocrysts and glasses, and implications for magma evolution and metal transport.-Geofluids, 10, 293-311. doi: 10.1111/j.1468-8123.2009.00272.x

KARAMATA, S. (1974A): The geological evolution of the area of Yugoslavia: The nature and movements of plates and importance of these properties and processes for metallogeny.- Metallogeny and concepts of the geotectonic developments of Yugoslavia, Belgrade, 109-118.

KARAMATA, S. (1974B): Geološki razvoj naše oblasti: karakteristike i pokreti nekih ploča i važnost tih karakteristika i procesa za metalogeniju [Geological development of our area: characteristics and movements of particular plates and importance of those features and processes to the metallogeny - in Serbian].- In: Metallogeny and conceptions of the geotectonic development of the Yugoslavia, Faculty of Mining and Geology, Belgrade, 89-97.

KEEVIL, N.B. (1942): Vapor pressures of aqueous solutions at high temperatures.Amer. Chem. Soc. J. 64, 841-850.

KILINC, I.A. \& BURNHAM, C.W. (1972): Partitioning of chloride between a silicate melt and coexisting aqueous phase from 2 to 8 kilobars.-Econ. Geol., 67, 231-235. doi: 10.2113 /gsecongeo.67.2.231

KISELINOV, H., PEYCHEV, K., GEORGIEV, S. \& PEYTCHEVA, I. (2014): New geochronology data on the Lower Cambrian age of the Frolosh Metamorphic Complex (Frolosh Unit) and Kadiytsa Formation-SW Bulgaria. Bul. Shk. Gjeol. 1/2014, Special Issue, Proceedings, XX Congress of the Carpathian-Balkan Geological Association, Tirana; 200-202, 2014.

KLEMM, L.M., PETTKE, T. \& HEINRICH, C.A. (2007): Hydrothermal evolution of the El Teniente deposit, Chile-Porphyry Cu-Mo ore deposition from low-salinity magmatic fluids.- Econ. Geol., 102, 1021-1045. doi: 10.2113/gsecongeo.102.6.1021

KLEMM, L.M., PETTKE, T. \& HEINRICH, C.A. (2008): Fluid and source magma evolution of the Questa porphyry Mo deposit, New Mexico, USA.- Min. Dep., 43, 533-552. doi: 10.1007/s00126-008-0181-7

KNIGHT, C.L. \& BODNAR, R.J. (1989): Synthetic fluid inclusions: IX. Critical PVTX properties of NaCl-H2O solutions.- Geoch. Cosmoch. Acta, 53, 3-8. doi: 10.1016/0016-7037(89)90267-6

KOCKEL, F., MOLLAT, H. \& GUNDLACH, H. (1975): Hydrothermaly altered and (Copper) mineralized Porphyritic Intrusions in the Serbo-Macedonian Massif (Greece).-- Min. Dep., 10, 195-204.

KODĚRA, P., HEINRICH, C. A., WÄLLE, M. \& LEXA, J. (2014): Magmatic salt melt and vapor: Extreme fluids forming porphyry gold deposits in shallow subvolcanic settings.- Geology, 42/6, 495-498. doi: 10.1130/G35270.1

KOVACEVIĆ, M., RAKIČEVIĆ, T. \& ARSOVSKI, M. (1973): Tolkuvač za geološka karta list Delčevo [Guide for geological map sheet Delčevo - in Macedonian].Geological survey of the Republic of Macedonia, Skopje, $55 \mathrm{p}$.

KOUNOV A (2002). Thermotectonic evolution of Kraishte, Western Bulgaria.- Dissertation ETH 14946, Zurich, $219 \mathrm{p}$.

KOUNOV, A., GRAF, J., QUADT, A.V., BERNOULLI, D., BURG, J.-P., SEWARD, D., IVANOV, Z. \& FANNING, M. (2012): Evidence for a "Cadomian" ophiolite and magmatic-arc complex in SW Bulgaria.- Precambrian Research, 212-213; 275-295.

LANDTWING, M., FURRER, C., REDMOND, P., PETTKE, T., GUILLONG, M. \& HEINRICH, C.A. (2010): The Bingham Canyon porphyry Cu-Mo-Au deposit. III. Zoned copper-gold ore deposition by magmatic vapour expansion.- Econ. Geol., $105,91-118$

LERCHBAUMER, L. \& AUDÉTAT, A. (2012): High Cu concentrations in vapor-type fluid inclusions: An artifact?.- Geoch. et Cosmoch. Acta, 88, 255-274. doi: 10.1016/j.gca.2012.04.033

LI, J.X., QIN, K.Z. \& LI, G.M. (2006): The basic characteristics of gold-rich porphyry copper deposits and their ore sources and evolving processes of high oxidation magma and ore-forming fluid.- Acta Petrol. Sin., 22, 678-88.

LI, G.M., LI, J.X., QIN, K.Z., ZHANG, T.P. \& XIAO, B. (2007): High temperature, salinity and strong oxidation ore-forming fluid at Duobuza gold-rich porphyry copper in the Bangonghu tectonic belt, Tibet: evidence from fluid inclusions study.Acta Petrol. Sin., 23, 935-952.

LI, J.X., LI, G.M., QIN, K.Z. \& XIAO, B. (2011): High-temperature magmatic fluid exsolved from magma at the Duobuza porphyry copper-gold deposit, Northern Tibet.- Geofluids, 11, 134-143.

LI, N., CHEN, Y.J., PIRAJNO, F. \& NI, Z.Y. (2013): Timing of the Yuchiling giant porphyry Mo system, and implications for ore genesis.- Min. Depos., 48/4, 505-524. doi: 10.1007/s00126-012-0441-4

LINDHORST, J.W. \& COOK, W.G. (1990): Gindinbung gold-silver deposit, Temora.Australas. Inst. of Min. and Metall. Monogr, 14/2, 1365-1370.

LINKE, W.F. (1965): Solubilities of inorganic and metal-organic compunds.- K-Z (4 $4^{\text {th }}$ Ed.) Washington, American Chemical Society, V. 2, 1,914 p. 
LOWELL, J.D. \& GUILBERT, J.M. (1970): Lateral and vertical alteration-mineralization zoning in porphyry ore deposits.- Econ. Geol., 65, 373-408. doi: 10.2113/ gsecongeo.65.4.373

MISRA, K. (2000): Understanding Mineral Deposits. - Kluwer Academic Publishers, Dodrecht, Netherland, 845 p. doi: 10.1007/978-94-011-3925-0

MOORE, W.J. \& NASH, J.T. (1974): Alteration and fluid inclusion studies of the porphyry copper ore body at Bingham, Utah.-Econ. Geol. 69, 631-645. doi: 10.2113/ gsecongeo.69.5.631

MOORE, F. \& MOORE, D.J. (1979): Fluid inclusion study of mineralization at St. Michaels Mount, Cornwall.- Trans. of the Inst. of Min. and Metall. (Sec.B), 88, 57-60.

NASH, J.T. (1976): Fluid-inclusion petrology-Data from porphyry copper deposits and application to exploration.- Geology and Resources of Copper Deposits, United States Department of Interior and Geological Survey, D1-D16.

NASH, J.T. \& THEODORE, T. (1971): Ore fluids in the porphyry copper deposit at Copper Caynon, Nevada.- Econ. Geol., 66, 385-399.

POTTER, R.W. II., BABCOCK, R.S. \& BROWN, D.L. (1977): New method for determining the solubility of salts in aqueous solutions at elevated temperatures.J. Res. U.S. Geol. Surv., 5/3, 389-395.

PROFFETT, J.M. (2003): Geology of the Bajo de la Alumbrera porphyry copper-gold deposit, Argentina.- Econ. Geol., 98, 1535-1574.

REDMOND, P.B., EINAUDI, M.T., INAN, E.E., LANDTWING, M.R. \& HEINRICH, C.A. (2004): Copper deposition by fluid cooling in intrusion-centered systems: New insights from the Bingham porphyry ore deposit, Utah.- Geology, 32, 217-220. doi: 10.1130/G19986.1

RICHARDS, J.P. (2003): Tectono-magmatic precursors for porphyry $\mathrm{Cu}-(\mathrm{Mo}-\mathrm{Au}) \mathrm{de}-$ posit formation.-Econ. Geol., 98, 1515-1534. doi: 10.2113/gsecongeo.98.8.1515

ROBERTSON, A., KARAMATA, S. \& ŠARIĆ, K. (2009): Overview of ophiolites and related units in the Late Palaeozoic-Early Cenozoic magmatic and tectonic development of Tethys in the northern part of the Balkan region.- Lithos, 108/1-4, 1-36.

ROEDDER, E. (1971): Fluid inclusion studies on the porphyry-type ore deposits at Bingham, Utah, Butte, Montana, and Climax, Colorado.- Econ. Geol., 66, 98-120.

ROEDDER, E. (1979): Fluid inclusions as samples of ore fluids.- In: BARNES, H.L. (ed.): Geochemistry of hydrothermal ore deposits: New York, Wiley, 684-737.

ROEDDER, E. (1984): Fluid inclusions.- Rev. Min., 12, 644 p.

ROEDDER, E. (1992): Fluid inclusion evidence for immiscibility in magmatic differentiation.- Geoch. Cosmoch. Acta, 56, 5-20. doi: 10.1016/0016-7037(92)90113-W

ROEDDER, E. \& COOMBS, D.S. (1967): Immiscibility in granitic melts, indicated by fluid inclusions in ejected granitic blocks from Ascension Island.- J. of Petrol., 8, $417-451$.

RUSK, B.G., REED, H.M. \& DILLES, H.J. (2008): Fluid inclusion evidence for magmatic-hydrothermal fluid evolution in the porphyry copper-molybdenum deposit at Butte, Montana.- Econ. Geol., 103/2: 307-334. doi: 10.2113/gsecongeo.103.2.307

SANTANA, M.M.U., MOURA, M.A., OLIVO, G., BOTELHO, N.F., KYSER, T.K. \& BÜHN, B. (2011): The La Unión $\mathrm{Au} \pm \mathrm{Cu}$ prospect, Camagüey District, Cuba: fluid inclusion and stable isotope evidence for ore-forming processes.- Min. Depos., 46/1, 91-104.

SEEDORFF, E., DILLES, J.H., PROFFETT, J.M., EINAUDI, M.T., ZUCHER, L., STAVAST, W.J.A., JOHNSON, D.A. \& BARTON, M.D. (2005): Porphyry deposits: characteristics and origin of hypogene features.- Econ. Geol., 100, 251-298.

SEO, J.H. \& HEINRICH, A.C. (2013): Selective copper diffusion into quartz-hosted vapor inclusions: Evidence from other host minerals, driving forces, and consequences for $\mathrm{Cu}-\mathrm{Au}$ ore formation.- Geoch. et Cosmoch. Acta, 113, 60-69. doi: 10.1016/j. gca.2013.03.016

SERAFIMOVSKI, T. (1990): Metalogenija na zonata Lece-Halkidiki [Metallogeny of the Lece-Chalkidiki zone - in Macedonian].- PhD Faculty of Mining and Geology, Stip, $380 \mathrm{p}$.

SERAFIMOVSKI, T. (1993): Strukturno-metalogenetski karakteristiki na zonata LeceHalkidiki: Tipovi na rudni naogjalista i distribucija [Structural metallogenetic characteristics of the Lece-Chakidiki zone: Types of Mineral Deposits and Distribution - in Macedonian with extended summary in English].- Spec. ed. of RGF Stip, 1, $328 \mathrm{p}$.

SERAFIMOVSKI, T., JANKOVIC, S. \& CIFLIGANEC, V. (1995): Alpine Metallogeny and Plate Tectonics in the SW Flank of the Carpatho-Balkanides.- Geol. Maced., 9/1, 3-14.

SERAFIMOVSKI, T., TOMSON, I.N. \& KOCNEVA, N.T. (1997): Alpine orogenic structures and metallogeny in the Serbo-Macedonian massif and the Vardar zone of the territory of Macedonia.- In: BOEV, B. \& SERAFIMOVSKI, S. (eds): Symposium-Annual Meeting Dojran, Proceed., 113-117.

SERAFIMOVSKI, T., TASEV, G., BLAZEV, K. \& VOLKOV, A. (2010): Major Alpine structures and $\mathrm{Cu}$-porphyry mineralization in the Serbo-Macedonian massif.Geol. Maced., 24/1, 39-48.

SERAFIMOVSKI, T. (2012): Elaborat od izvršenite detalni geološki istražuvanja na mineralnata surovina bakar na lokalnosta Kadiica, Pehčevo [Elaborate of detailed geological explorations of copper in the Kadiica locality, Pehcevo - in Macedo- nian].- Faculty of Natural and Technical Sciences for DPTU Kadiica DOOEL Pehčevo, $208 \mathrm{p}$.

SHEPHERD, T., RANKIN, A.H. \& ALDERTON, D.H.M. (1985): A practical guide to fluid inclusion studies.- Blackie, Glasgow, $240 \mathrm{p}$.

SHINOHARA, H. (1994): Exsolution of immiscible vapor and liquid phases from a crystallizing silicate melt: implications for chlorine and metal transport.- Geoch. et Cosmoch. Acta, 58, 5215-5221. doi: 10.1016/0016-7037(94)90306-9

SILLITOE, H.R. (1973): The tops and bottoms of porphyry copper deposits.- Econ. Geol., 68, 799-815. doi: 10.2113/gsecongeo.68.6.799

SOURIRAJAN, S. \& KENNEDY, G.C. (1962): The system H2O-NaCl at elevated temperatures and pressures.-Amer. J. Sci., 260, 115-141.

STERNER, S.M., HALL, D.L. \& BODNAR, R.J. (1988): Synthetic fluid inclusions. V. Solubility relations in the system $\mathrm{NaCl}-\mathrm{KCl}-\mathrm{H}_{2} \mathrm{O}$ under vapor saturated conditions.Geoch. Cosmoch. Acta, 52, 989-1005. doi: 10.1016/0016-7037(88)90254-2

STOJANOV, R. (1980): Vulkanska doma Plavica, polimetalični mineralizacii i neposredni alteracii [Volcanic dome Plavica, polymetalic mineralizations and adjacent alterations - in Macedonian].- Symposia Alteration of rocks and minerals, 100 years of geological school and science in Serbia, Belgrade, p. 291.

STOJANOV, R. \& ALEKSANDROV, M. (1990): Tercieren vulkanizam vo zonata SasaToranica [Tertiary volcanism in the Sasa-Toranica zone - in Macedonian].- XII Congr. of geol. of Yugoslavia, Ohrid, 371-386.

STOJANOV, R., HADŽI-PETRUSEV, B. \& ALEKSANDROV, M. (1995): Daciticrhyolitic volcanic products at Bukovic-Kadijca(Pehčevo district) and the related porphyry copper mineralization - Geol. Balk., 25-5/6, 83-90.

STOJANOVIĆ, M. (1969): Geološki sklop na poširokata oblast Bukovik (Pehčevo), so pregled na geološko-mineraloškite i genetskite karakteristiki na naogjalištata na limonitski breči [Geological setting of wider area of the Bukovik (Pehčevo), with review of geological-mineralogical and genetic features of limonite breccia deposits - in Macedonian].- Papers of Geol. Surv. of the Rep. of Maced., 14, 27-36.

TAYLOR, A.V.JR. (1935): Ore deposits at Chuquicamata, Chile in Copper resources of the world. $-16^{\text {th }}$ Internat. Geol. Cong., Washington, 2, 473-484

TASEV, G. (2010): Metalogenija na polimetaličniot rudonosen system Bukovik-Kadiica [Metallogeny of the polymetallic ore bearing system Bukovik-Kadiica - in Macedonian].- PhD, University "Goce Delčev"-Stip, Faculty of Mining, geology and polytechnics, $207 \mathrm{p}$.

THIERY, R., KERKHOF, AM. \& DUBESSY, J. (1994): VX properties of $\mathrm{CH}_{4}-\mathrm{CO}_{2}$ and $\mathrm{CO}_{2}-\mathrm{N}_{2}$ fluid inclusions: modeling for $\mathrm{T}<31{ }^{\circ} \mathrm{C}$ and $\mathrm{P}<400$ bars.- Eur. J. Min., 6 , $753-771$.

THOMPSON, J.F.H., LESSMAN, J. \& THOMPSON, A.J.B. (1986): The Temora goldsilver deposit: A newly recognized style of high sulfur mineralization in the Lower Paleozoic of Australia.- Econ. Geol., 81, 732-738. doi: 10.2113/gsecongeo.81.3.732

ULRICH, T., GÜNTHER, D. \& HEINRICH, C.A. (2002): Evolution of a porphyry Cu$\mathrm{Au}$ deposit, based on LA-ICP-MS analysis of fluid inclusions, Bajo de la Alumbrera, Argentina.-Econ. Geol., 97, 1888-1920. doi: 10.2113/gsecongeo.97.8.1889

URQUETA, E., KYSER, K., CLARK, A., STANLEY, C. \& OATES, C. (2009): Lithogeochemistry of the Collahuasi porphyry $\mathrm{Cu}-\mathrm{Mo}$ and epithermal $\mathrm{Cu}-\mathrm{Ag}(-\mathrm{Au})$ cluster, northern Chile: Pearce element ratio vectors to ore-- Geochem. Expl. Envir. Anal, 9, 9-17.

VANKO, D.A., BODNAR, R.J. \& STERNER, S.M. (1988): Synthetic fluid inclusions. VIII. Vapor-saturated halite solubility in part of the system $\mathrm{NaCl}-\mathrm{CaCl}_{2}-\mathrm{H}_{2} \mathrm{O}$, with application to fluid inclusions from oceanic hydrothermal systems.- Geoch. Cosmoch. Acta, 52, 2451-2456.

VEKSLER, I.V. (2004): Liquid immiscibility and its role at the magmatic-hydrothermal transition: a summary of experimental studies.- Chem. Geol., 210, 7-31. doi: 10.1016/j.chemgeo.2004.06.002

VOLKOV, A.V., TASEV, G., PROKOF'EV, V.YU., SERAFIMOVSKI, T., TOMSON, I.N. \& SIDOROV, A.A. (2008): Formation Conditions of Copper Porphyry Mineralization in the Kadica-Bukovik Ore District, Eastern Macedonia.- Dokl. Earth Sci., 421/5, 769-773.

WEBSTER, J.D. (1997): Exsolution of magmatic volatile phases from Cl-enriched mineralizing granitic magmas and implications for ore metal transport.- Geoch. Cosmoch. Acta, 61, 1017-1029. doi: 10.1016/S0016-7037(96)00395-X

WEBSTER, J.D. \& MANDEVILLE, C.W. (2007): Fluid immiscibility in volcanic environments.- Rev. Min. Geoch., 65, 313-62. doi: 10.2138/rmg.2007.65.10

WESTRA, G. (2005): Remaining exploration potential in the Kadiica porphyry copper prospect near Berovo, Macedonia.- Internal report prepared for Phelps Dodge Corp., 11 p.

WILKINSON, J.J. (2001): Fluid inclusions in hydrothermal ore deposits.- Lithos, 55, 229-272. doi: 10.1016/S0024-4937(00)00047-5

WILLIAMS-JONES, E.A. \& HEINRICH, A.C. (2005): $100^{\text {th }}$ Anniversary special paper: Vapor transport of Metals in Magmatic-Hydrothermal Systems.- Econ. Geol., 100, 1287-1312.

WORMALD, R.J. \& PRICE, R.C. (1990): The gabbro-quartz monzonite-alkali granite association in southern NSW: Implications for intrusive related gold mineralization.- Geological Society of Australia Abstracts Series, 25, 265-266. 
XIE, Y.L., YI, L.S., XU, J.H., LI, G.M., YANG, Z.M. \& YIN, S.P. (2006): Characteristics of ore-forming fluids and their evolution for Chongjiang copper deposit in Gangdese porphyry copper belt, Tibet: evidence from fluid inclusions.- Acta Petrol. Sin., 22, 1023-1030.

ZAGORCHEV, I. (1987): Stratigraphy of the diabase-phyllitoid complex in SW Bulgaria.- Geol. Balc., 17/3, 3-14.

ZAGORCHEV, I. (1995): Pre-Palaeogene Alpine tectonics in Southwestern Bulgaria.Geol. Balc., 25/5-6, 91-112.

ZAGORCHEV, I., MOORBATH, S. \& LILOV, P. (1987): Radiogeochronological data about the Alpine magmatism in the western part of the Rhodope massif.- Geol. Balc., 17/2, 59-71.

ZAGORCHEV, I. \& MILOVANOVIC, D. (2006): Deformations and metamorphism in the eastern parts of the Serbo-Macedonian Massif.- Proceed. $18^{\text {th }}$ Congress Carpatho Balkan Geological Association, Belgrade, 670-673.

ZAGORCHEV, I., DABOVSKI, C. \& DUMURDZANOV, N. (2008): Tectonic structure of Bulgaria and Macedonia based on TRANSMED TRANSECT III.- In: BOEV, B. \& SERAFIMOVSKI, T. (eds): Proceedings: The First Congress of geologists of the Rep. of Macedonia, 75-83.

ZAGORCHEV, I., BALICA, C., BALINTONI, I., KOZHOUKHAROVA, E., DUMITRESCU, R., SABAU, G. \& NEGULESCU, E. (2011A): New Isotopic Data on the Metamorphic Rocks in SW Bulgaria. $-3^{\text {rd }}$ International Symposium on the Geology of the Black Sea Region, Bucharest, 223-225.

ZAGORCHEV, I., BALICA, C., BALINTONI, I., KOZHOUKHAROVA, E., DUMITRESCU, R., SABAU, G. \& NEGULESCU, E. (2011B): New isotopic data on the Cadomian age of the Frolosh metamorphic complex and the Struma diorite complex.- Geosciences' 2011, Sofia, 77-78.

ZAGORCHEV, I., BALICA, C., BALINTONI, I., KOZHOUKHAROVA, E., SĂBĂU, G. \& NEGULESCU, E. (2012): Palaezoic evolution of the Ograzhden Unit (SerboMacedonian Massif, Bulgaria and Macedonia).- In: JOVANOVSKI, M. \& BOEV, B. (eds): Proceedings Book: Second Congress of Geologists of the Republic of Macedonia, Krusevo, Spec. Issue of Geol. Maced. No. III, 13-18.

ZAGORCHEV, I., BALICA, C., KOZHOUKHAROVA, E., BALINTONI, I., SĂBĂU, G. \& NEGULESCU, E. (2015): Cadomian and post-cadomian tectonics west of the Rhodope Massif - The Frolosh greenstone belt and the Ograzhdenian metamorphic supercomplex.- Geol. Maced., 29/2, 101-132.

ZHANG, D.H., ZHANG, W.H. \& XU. G.J. (2001): Exsolution and evolution of magmatic hydrothermal fluids and their constraints on the porphyry ore-forming system.- Earth Sci. Front., 8, 194-202.

CIFLIGANEC, V. (1993): Copper mineralization in the Republic of Macedonia: Types and Distribution patterns: with special reference to the porphyry copper deposit Bucim.- University "Sts. Cyril and Methodius"- Skopje, Faculty of Mining and Geology, Special Issue 1, 303 p. 